Article

\title{
Are the Fouta Djallon Highlands Still the Water Tower of West Africa?
}

\author{
Luc Descroix 1,2,*, Bakary Faty ${ }^{3}$, Sylvie Paméla Manga ${ }^{2,4,5}$, Ange Bouramanding Diedhiou 6 (D), \\ Laurent A. Lambert 7 (D), Safietou Soumaré 2,8,9, Julien Andrieu 1,9, Andrew Ogilvie 10 (D), \\ Ababacar Fall ${ }^{8}$ (D), Gil Mahé 11(D), Fatoumata Binta Sombily Diallo ${ }^{12}$, Amirou Diallo ${ }^{12}$, \\ Kadiatou Diallo ${ }^{13}$, Jean Albergel ${ }^{14}$, Bachir Alkali Tanimoun ${ }^{15}$, Ilia Amadou ${ }^{15}$, \\ Jean-Claude Bader ${ }^{16}$, Aliou Barry ${ }^{17}$, Ansoumana Bodian ${ }^{18} \mathbb{D}^{\mathbb{D}}$, Yves Boulvert ${ }^{19}$, \\ Nadine Braquet ${ }^{20}$, Jean-Louis Couture ${ }^{21}$, Honoré Dacosta ${ }^{22}$, Gwenaelle Dejacquelot ${ }^{23}$, \\ Mahamadou Diakité ${ }^{24}$, Kourahoye Diallo ${ }^{25}$, Eugenia Gallese ${ }^{23}$, Luc Ferry ${ }^{20}$, Lamine Konaté ${ }^{26}$, \\ Bernadette Nka Nnomo ${ }^{27}$, Jean-Claude Olivry ${ }^{19}$, Didier Orange ${ }^{28}$ (D), Yaya Sakho ${ }^{29}$, \\ Saly Sambou ${ }^{22}$ and Jean-Pierre Vandervaere ${ }^{30}$
}

1 Museum National d'Histoire Naturelle, UMR PALOC IRD/MNHN/Sorbonne Université, 75231 Paris, France; Julien.ANDRIEU@univ-cotedazur.fr

2 LMI PATEO, UGB, St Louis 46024, Senegal; s.manga4555@zig.univ.sn (S.P.M.); s.soumare913@zig.univ.sn (S.S.)

3 Direction de la Gestion et de la Planification des Ressources en Eau (DGPRE), Dakar 12500, Senegal; bakaryfaty@gmail.com

4 Département de Géographie, Université Assane Seck de Ziguinchor, Ziguinchor 27000, Senegal

5 UFR des Sciences Humaines et Sociales, Université de Lorraine, 54015 Nancy, France

6 Master SPIBES/WABES Project (Centre d'Excellence sur les CC) Bingerville, Université Félix Houphouët Boigny, 582 Abidjan 22, Côte d'Ivoire; bouramanding@gmail.com

7 Doha Institute for Graduate Studies, BP 200592 Doha, Qatar; llambert@qu.edu.qa

8 Ecole Polytechnique de Thiès, Laboratoire des Sciences et Techniques de l'Eau et de l'Environnement, LaSTEE, Thiès BP A10, Senegal; afall@ept.sn

9 ESPACE, Université Côte d'Azur, 06204 Nice, France

10 UMR G-EAU, IRD (AgroParisTech, Cirad, INRAE, MontpellierSupAgro, University of Montpellier), Dakar 12500, Senegal; andrew.ogilvie@ird.fr

11 IRD HSM, Case MSE, Université Montpellier, 300 avenue Emile Jeanbrau, 34090 Montpellier, France; gilmahe@hotmail.com

12 CERE Centre d'Etudes et de Recherches sur l'Environnement, UGANC Conakry, Conakry 001, Guinea; binetasombily@yahoo.fr (F.B.S.D.); damirou2013@gmail.com (A.D.)

13 Institut Universitaire des Hautes Etudes IUHEG, Conakry et GEOPROSPECT, Conakry 001, Guinea; Kadiatoudiallo5459@gmail.com

14 Montpellier SupAgro, UMR LISAH, IRD, INRA, University of Montpellier, 34090 Montpellier, France; jean.albergel@ird.fr

15 NBA (ABN) Niger Basin Authority, Niamey 8000, Niger; balkaly83@gmail.com (B.A.T.); i_amadou@yahoo.fr (I.A.)

16 UMR G-EAU, IRD (AgroParisTech, Cirad, INRAE, MontpellierSupAgro, Univ Montpellier), Univ Montpellier, 34196 Montpellier, France; jean-claude.bader@ird.fr

17 Direction Nationale de l'Hydraulique, Conakry 001, Guinea; barryaliou55@yahoo.fr

18 Laboratoire Leïdi “Dynamique des Territoires et Développement”, Université Gaston Berger (UGB), BP 234-Saint Louis 46024, Senegal; ansoumana.bodian@ugb.edu.sn

19 Senior Investigator of IRD; yj.boulvert@gmail.com (Y.B.); jean-claude.olivry@wanadoo.fr (J.-C.O.)

20 UMR G-EAU, IRD (AgroParisTech, Cirad, INRAE, MontpellierSupAgro, Univ Montpellier), Conakry 001, Guinea; nadine.braquet@ird.fr (N.B.); luc.ferry3435@gmail.com (L.F.)

21 Independent Consultant, 34980 Combaillaux, France; jean-louis.couture@wanadoo.fr

22 Département de Géographie, Faculté des Lettres et Sciences Humaines, Université Cheikh Anta Diop, Dakar 12500, Senegal; honore.dacosta@ucad.edu.sn (H.D.); sambousaly@gmail.com (S.S.) 
23 Grdr Migrations, Citoyenneté, Développement, 93100 Montreuil, France; gwenaelle.dejacquelot@grdr.org (G.D.); eugenia.gallese@grdr.org (E.G.)

24 OMVS Organisation Pour la Mise en Valeur du Bassin du Fleuve Sénégal, Dakar 12500, Senegal; diakitemm2@gmail.com

25 FPFD, Fédération des Paysans du Fouta Djallon BP 52 PITA, Timbi Madina 7311, Guinea; kourahoye@yahoo.fr

26 OMVG Organisation pour la Mise en Valeur du Bassin du Fleuve Gambie, Dakar 12500, Senegal; lkonate@omvg.sn

27 Institut de Recherches Géologiques et Minières, Centre de Recherches Hydrologiques, Yaoundé BP 4110, Cameroon; bnnomo@gmail.com

28 IRD, Cirad, INRAE, Montpellier SupAgro, UMR Eco\&Sols, University of Montpellier, 34196 Montpellier, France; didier.orange@ird.fr

29 SENASOL, Service National des Sols, Conakry 001, Guinea; mouctaryaya3@gmail.com

30 UMR IGE Univ Grenoble/Alpes, IRD, CNRS, Grenoble INP, Université Grenoble Alpes, 38058 Grenoble, France; jean-pierre.vandervaere@univ-grenoble-alpes.fr

* Correspondence: luc.descroix@ird.fr; Tel.: +33-678-92-06-84

Received: 31 July 2020; Accepted: 10 September 2020; Published: 22 October 2020

\begin{abstract}
A large share of surface water resources in Sahelian countries originates from Guinea's Fouta Djallon highlands, earning the area the name of "the water tower of West Africa". This paper aims to investigate the recent dynamics of the Fouta Djallon's hydrological functioning. The evolution of the runoff and depletion coefficients are analyzed as well as their correlations with the rainfall and vegetation cover. The latter is described at three different space scales and with different methods. Twenty-five years after the end of the 1968-1993 major drought, annual discharges continue to slowly increase, nearly reaching a long-term average, as natural reservoirs which emptied to sustain streamflows during the drought have been replenishing since the 1990s, explaining the slow increase in discharges. However, another important trend has been detected since the beginning of the drought, i.e., the increase in the depletion coefficient of most of the Fouta Djallon upper basins, as a consequence of the reduction in the soil water-holding capacity. After confirming the pertinence and significance of this increase and subsequent decrease in the depletion coefficient, this paper identifies the factors possibly linked with the basins' storage capacity trends. The densely populated areas of the summit plateau are also shown to be the ones where vegetation cover is not threatened and where ecological intensification of rural activities is ancient.
\end{abstract}

Keywords: Fouta Djallon; water tower; depletion (or recession) coefficient; runoff coefficient; soil water holding capacity; basement; sandstone; Fula society

\title{
1. Introduction: Statements and State of the Art
}

The Fouta Djallon receives some of the greatest rainfall in West Africa. Although rainfall decreases inland from the coast, where Conakry receives more than $4000 \mathrm{~mm}$ yearly, to the mountains, the highlands, which separate the coastal basins from the great "sudano-sahelian" basins of Senegal and Niger Rivers, have annual precipitation ranging from 1800 to $2300 \mathrm{~mm}$. On the northern slope, annual rainfall ranges from 1300 to $2000 \mathrm{~mm}$. This is sufficient to ensure significant streamflows on both the coastal and continental hillslopes of the Fouta Djallon and the "Guinean Dorsale", its natural extension southeastward [1,2]. At the continental scale, the Fouta Djallon is one of the two great "water towers" of Northern sub-Saharan Africa (Figure 1), the other one being in Ethiopia [3,4]. 


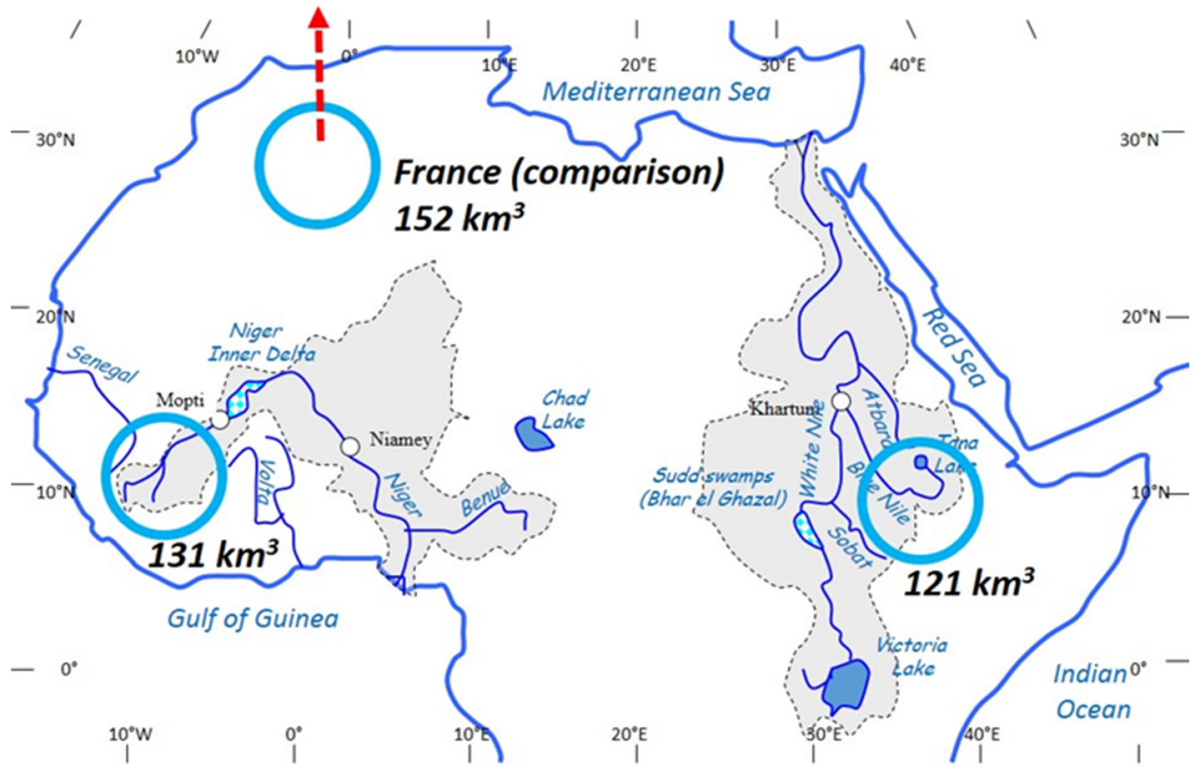

$37 / 44$

(a)

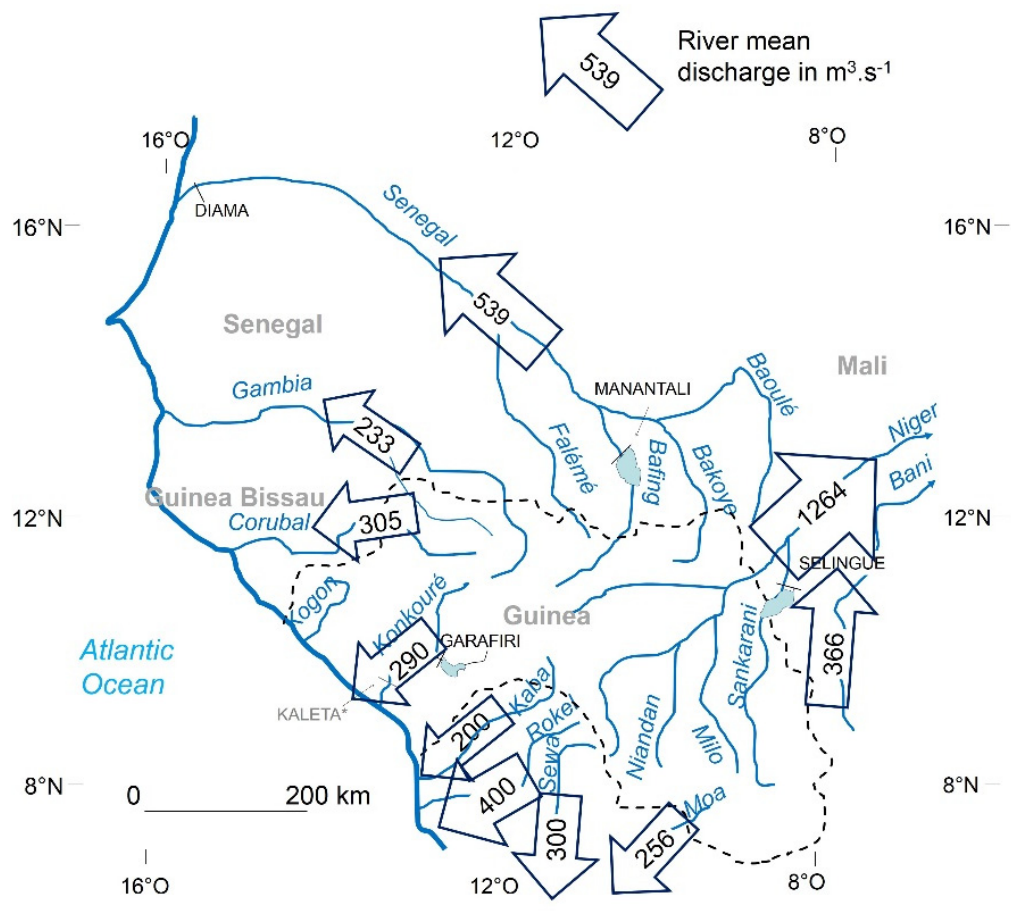

(b)

Figure 1. Cont. 


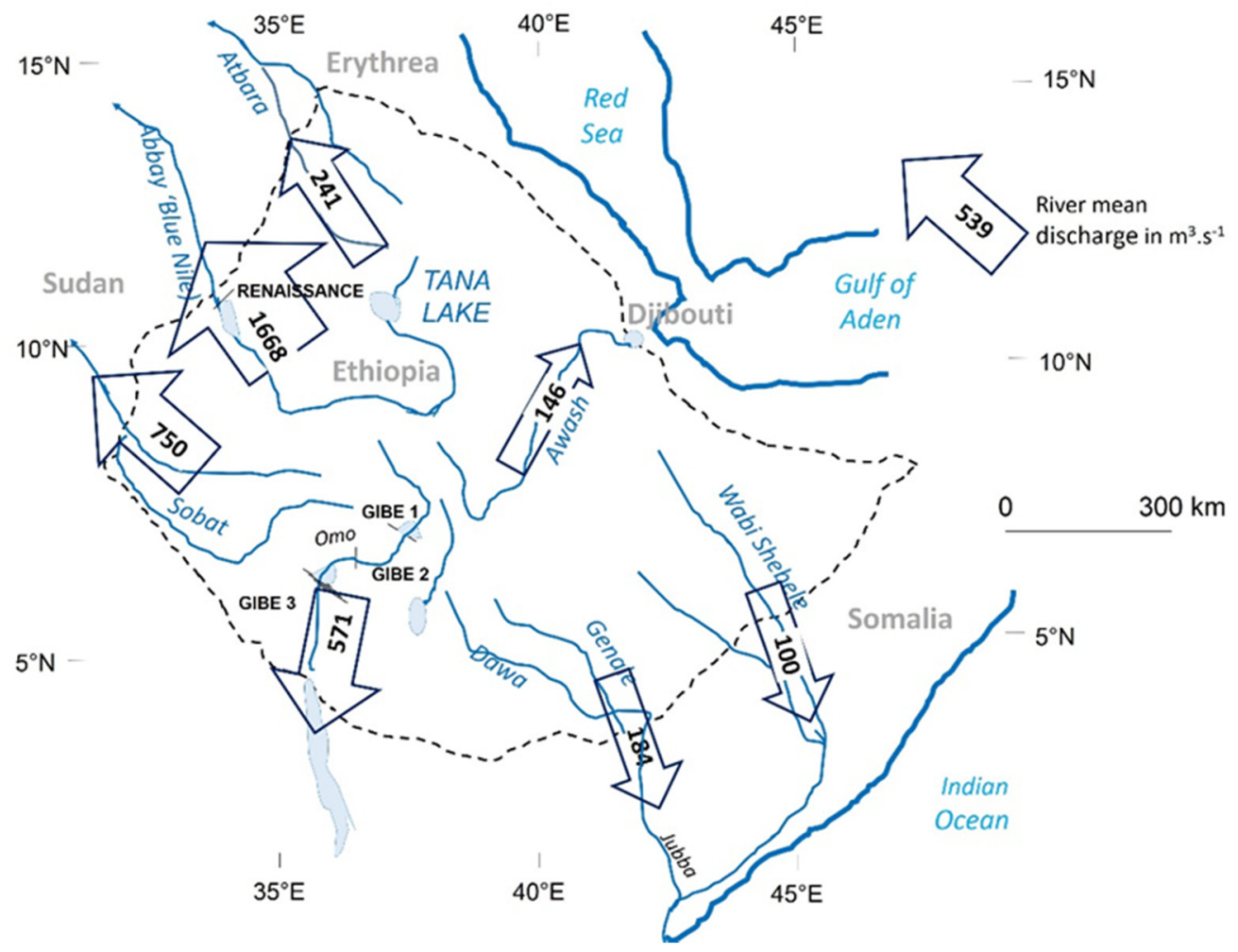

(c)

Figure 1. The two main natural water towers of northern sub-Saharan Africa and their 1951-2000 mean annual discharges; (a) comparison of the water towers (total discharges of French rivers is given for comparison purposes); (b) the Guinean water tower; (c) the Ethiopian water tower.

The Fouta Djallon highlands are unanimously recognized as the 'water tower' of West Africa as they constitute the source of many transboundary rivers and their tributaries in the region. Table 1 gives the dependence rate of some countries on the FD rivers. In this paper, the acronym 'FD' refers to the Fouta Djallon and the broader Guinean Dorsale (Figure 2) that runs southeastwards from the Fouta Djallon mountains, in Guinea, to the Nimba mountains, on the border with Côte d'Ivoire. By contrast, the acronym 'FDss' refers to the Fouta Djallon stricto sensu, which only constitutes the northwestern side of the Guinean Dorsale.

Table 1. Dependence rate (\%) from water coming of the Fouta Djallon highlands of the concerned West African countries [5].

\begin{tabular}{ccc}
\hline Country & $\begin{array}{c}\text { \% of Surface Water Resources } \\
\text { Originating in the Fouta Djallon }\end{array}$ & Concerned River Basins \\
\hline Mauritania & 96 & Senegal \\
Gambia & 63 & Gambia \\
Senegal & 60 & Senegal, Gambia, Anyamba/Geba \\
Guinea-Bissau & 48 & Corubal/Koliba, Anyamba/Geba \\
Mali & 55 & Senegal, Niger \\
Niger & 70 & Niger \\
\hline
\end{tabular}




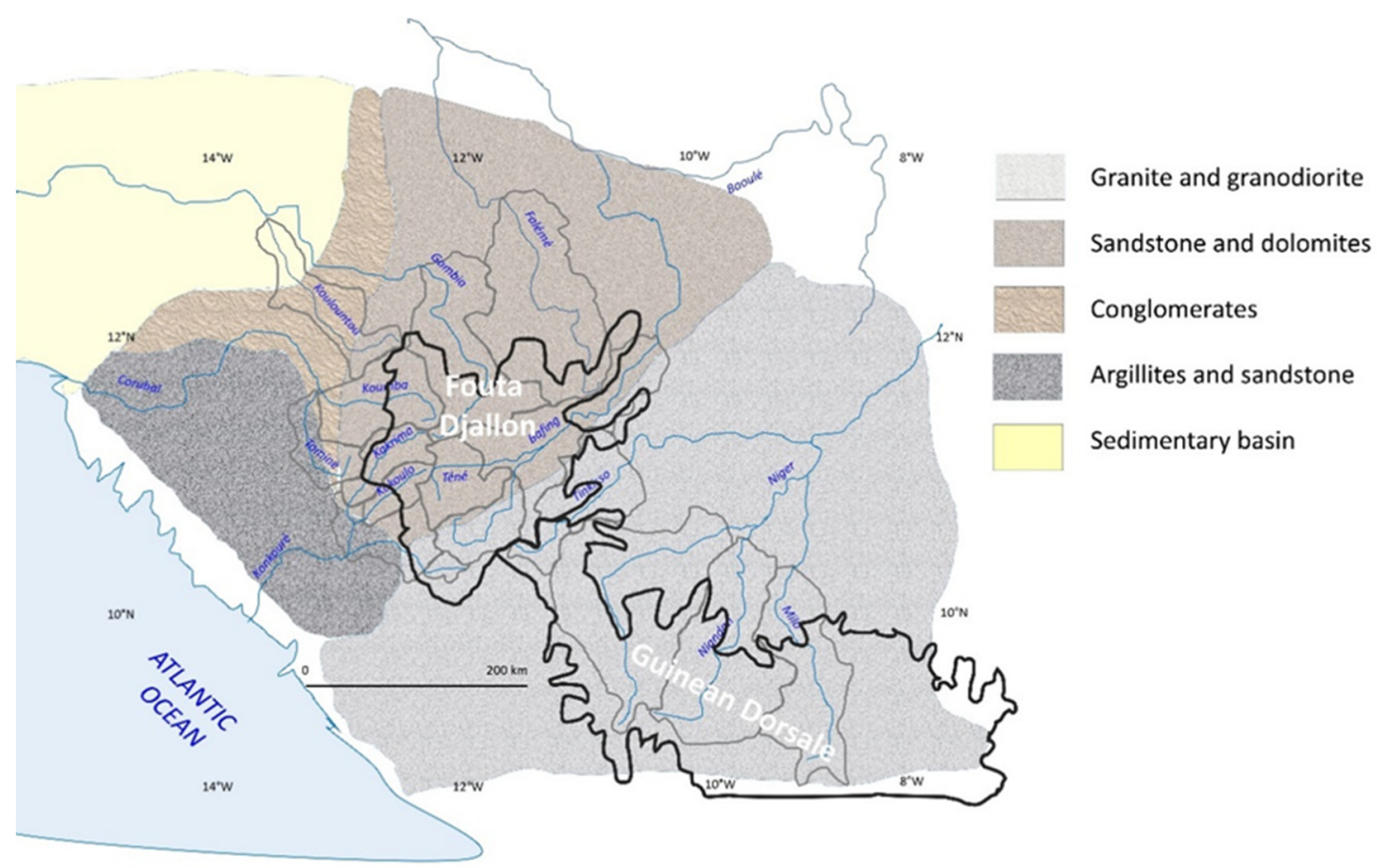

Figure 2. The main geological parts of the Fouta Djallon and Guinean Dorsale ensemble.

The range gathers the sources of the three main West Sudano-Sahelian rivers: the Gambia River, the sources of the Bafing-Falémé complex which form the Senegal River after the confluence of the Bafing and the Bakoye in Mali, and those of the Niger River and its Guinean tributary on the left bank, the Tinkisso [2]. The range also feeds the two main rivers of the Atlantic side of Guinea, the Kouba/Koumba and the Tominé, which become the Koliba and then the Rio Corubal in Guinea Bissau, as well as the Konkouré complex, and the main rivers crossing Sierra Leone and parts of Liberia.

\subsection{What Does Not Change}

The geological context of the Fouta Djallon differs from a natural water tower. The entire range can be divided into a Precambrian and mostly granitic basement in the south east and a sedimentary ensemble in the north west. The latter is mostly composed of sandstone with doleritic sills and intercalations of argillites (Figure 2). The separation follows a virtual Conakry-Bamako line [6]. In the FDss, the granite is widely covered by hundreds of meters of sandstone, dolomites, and argillites, with frequent sills of dolerites, none of which constitutes a good natural reservoir. Mamedov et al. (2010) [7] estimated the sandstone-quartzite-argillite thickness as ranging from 1500 to $4000 \mathrm{~m}$. The FDss is itself divided into three geological contexts: a small granitic area southward, the western sandstone area (soft sandstone and shale with some injections of dolerites), and the northwestern doleritic FD, which is also mostly composed of sandstone and shale, but which features a large number of outcropping sills and dolerite veins. Boulvert [6] noticed that these thick sandstone plateaus are separated by the incisions (of more than $700 \mathrm{~m}$ ) of the so-called 'Atlantic southern rivers' (i.e., the Kokoulo, the Kakrima, and the Koumba), highlighted by spectacular sandstone cornices, gorges, and waterfalls. The Guinean Dorsale is mostly an Archean granitic basement with few sills of dolerites and few outcrops of gneiss and quartzite [2]. All the Upper Niger basin and a part of the Konkouré River basin constitute a granitic basement, locally covered by sandstone and the typical 'lateritic pan'. The common characteristics of the whole mountain area of Guinea is the great extension of the 'bowe', i.e., lateritic plateaus composed of ferruginous and overall aluminous crusts [8].

However, no clear difference can be noticed in their hydrological behavior, most probably due to their similarly high levels of imperviousness. Infiltration exists at the FD scale (faults, cracks, 
and fractures, very few permeable rocks, local shale, and green rocks), but not at the sample scale. Most of the rocks are either completely impervious (granite, dolerites, quartzite) or mainly impervious (sandstone), except their alterites. In the entire FD, the rocks have a very low water storage capacity [2]. However, Boulvert [8] highlighted the extension of "paleo-crypto karsts" in the Bowe area of Guinea, which covers most of the Fouta Djallon. Therefore, the role of possible occulted streamflows remains to be analyzed.

The main characteristics of the FDss, which are common to the entire FD, can be summarized by the following [9]:

- the total absence of a generalized water table and of continuous groundwater reservoir [9]. There are only small and localized aquifers, well known by the local people [10].

- the very low mineral concentration of water (lower than $50 \mathrm{mg} \mathrm{L}^{-1}$ ). The average of dissolved load in total sampling observed by Orange (1990a) [9] is only $35 \mathrm{mg} \mathrm{L}^{-1}$, due to the sandstone and/or granite predominance and the importance of stable lateritic crusts [9]. This relatively old finding remains overall coherent and in line with a series of small sampling tests made in the FDss by the authors in March and May 2019. In 28 samples taken at an elevation of less than $800 \mathrm{~m}$, the mineral concentration of water was on average $55 \mathrm{mg} \cdot \mathrm{L}^{-1}$ (standard deviation $=74$, with values ranging from 6.5 to 414 ), and in 14 samples taken at an elevation higher than $800 \mathrm{~m}$, the mineral concentration was on average $24.5 \mathrm{mg} \cdot \mathrm{L}^{-1}$ (standard deviation $=14.8$, values from 6.5 to 53).

- the stationary geochemical regime: the alteration profile deepening $\left(4.6 \mathrm{~mm} \cdot \mathrm{yr}^{-4}\right)$ is slightly higher than soil erosion $\left(4.2 \mathrm{~mm} \cdot \mathrm{yr}^{-4}\right)[9,10]$.

The FD's overall impermeability strongly impacts surface water behavior. All of the geological context display the same functioning: very weak discharges during the dry season (from December to June), because they are not supported by groundwater. In contrast, at the occurrence of the first monsoon rainfall events (in June or July), discharges increase suddenly to peak in September, with the rainfall peak [2].

The impervious geology of most of the FD mountains $[9,11]$ leads to high runoff and recession coefficients in the main rivers, due to a very low soil water-holding capacity on the one hand and due to the above-mentioned absence of a generalized water tables on the other.

The monsoon lasts five to six months a year in the core part of the highlands, and annual precipitation is very low during the dry season. The low yet permanent streamflows of the main rivers are then fed by the emptying of the eight thousand small wetlands (commonly settled on alterites), of the thin aquifers, and of the free water of the lowlands alongside rivers and streams of the whole Fouta Djallon and Guinean Dorsale.

\subsection{What Could Change}

D'Aubreville (1947) [12] and then Maignien (1966) [13] were impressed by the great extension of "ferrallitic pans in Guinea". The former thought that the formation of these "bowe" (sing. "bowal"), or "bowalisation" (as the process), is still ongoing, yet most of them have proven to be fossils [8]. These are not evidence of any land degradation processes and results.

During the 1940s and 50s, geographers [14-16] such as Richard-Molard (1943), Pouquet (1956, 1960), agronomists [17] like Sudres (1947), or foresters [12] (e.g., D'Aubreville, 1947) were studying the impact of deforestation and erosion before the 70s [8].

The most densely populated area is the summit of the FDss (around Labé and Mali town) and its historical core. This location is very rainy, but it allows very poor water storage. People encounter severe problems in drinking water supply and even greater challenges to obtain water to irrigate a second or third yearly crop and produce enough food for the entire population.

As observed in the Sahel, the decrease in discharge during the prolonged rainfall deficit (1968-1993) of the Sahel's so-called "Great Drought" is approximately twice that of the rainfall [18]. During the 
drought, the authors highlighted that the severe rainfall deficit provoked for the first time in the Senegal River an exponential increase of the recession (or depletion) coefficient, which was stable for 70 years $\left(\mathrm{a}=0.0186 \mathrm{~d}^{-1}\right)$ and which strongly increased to reach 0.038 in 1984 [19]. This long "Great Drought" (Figure 3) led to a lasting degradation of the hydrological system. In Guinean areas, the decrease in discharges lasted 10 to 15 years. The increase in recession coefficients also lasted for years beyond the end of the drought. In 1997, Bricquet et al. [20] showed that despite the observed rainfall recovery, discharges did not begin to increase again at that time. This was due to the necessary refilling of the various natural storages such as surface and sub-surface reservoirs, and streamflows recovered over more than a decade [21]. Figure 4 [1] provides the spatial distribution of rainfall.

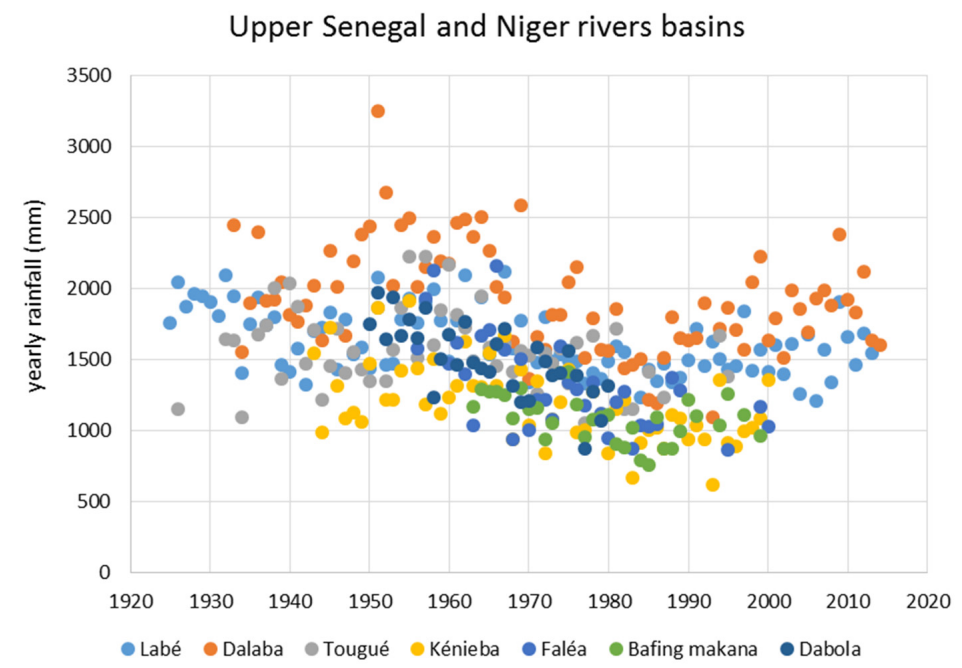

(a)

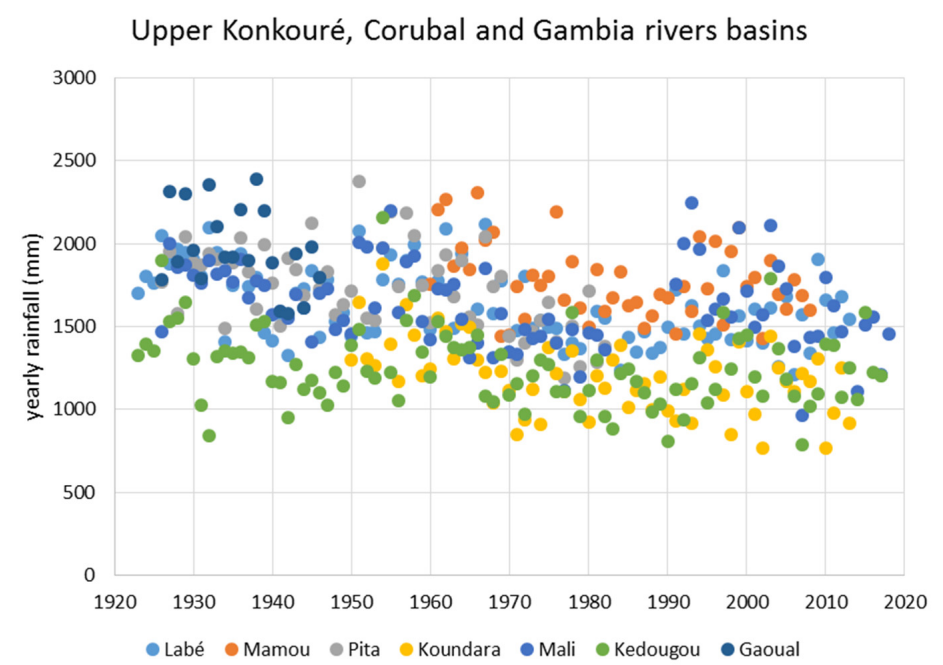

(b)

Figure 3. Rainfall evolution in the Fouta Djallon mountains since 1923; (a) Senegal and Niger upper basins. (b) Konkouré, Corubal, and Gambia rivers basins. Dots represent the annual total rainfall (ATR), in mm. 


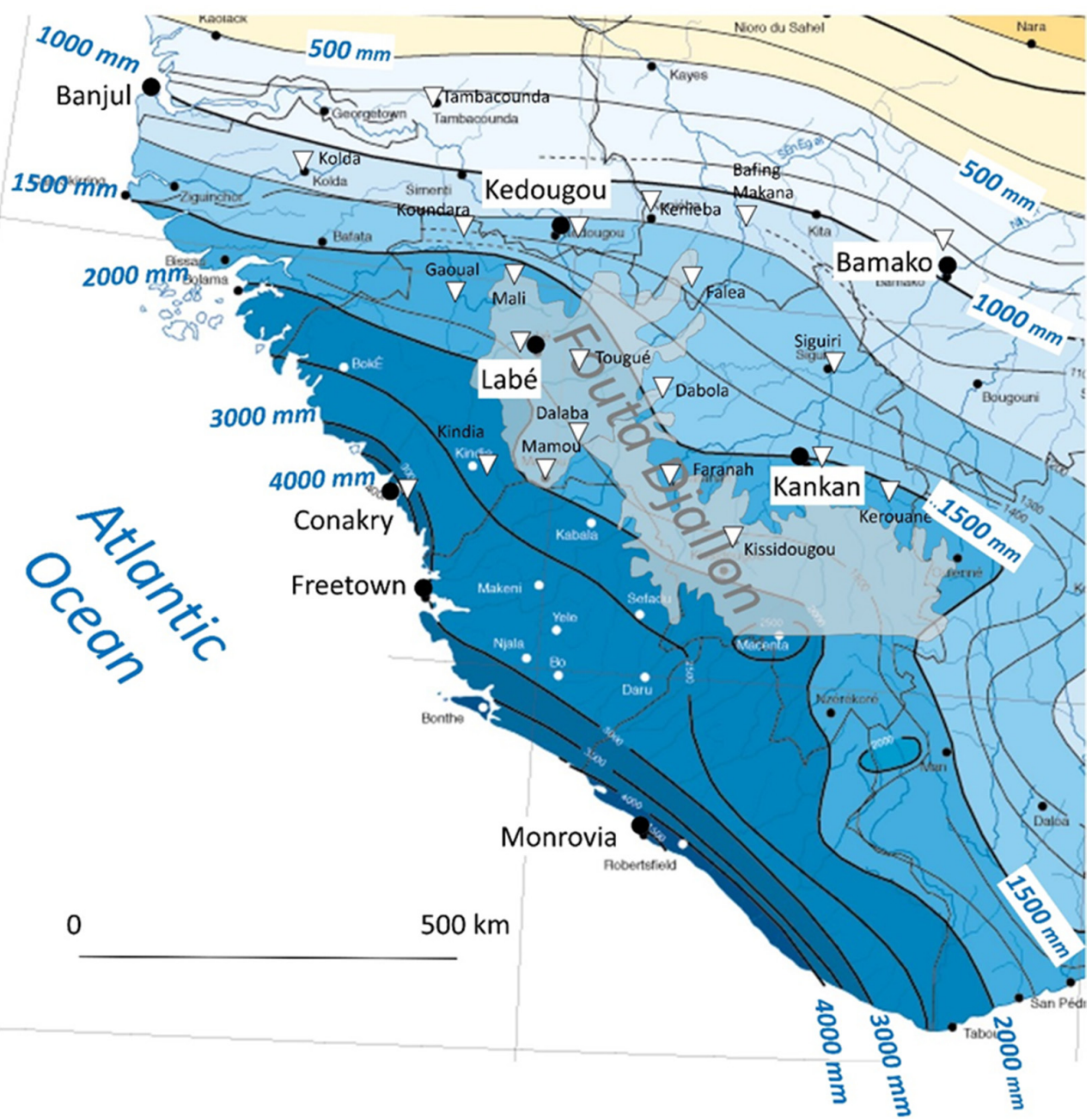

Figure 4. Rainfall spatial distribution (1950-2000) [1] and location of rain gauges (white triangles) used to unskew CHIRPS data.

However, Gomis observed in 2000 [22] that the rainfall recovery led to a decrease in the recession coefficient of the Gambia River. In the Bafing basin (Upper Senegal basin), this slow and progressive discharge recovery was also characterized by a decrease in the recession coefficient, from $0.025 \mathrm{~d}^{-1}$ in 1972-1994 to $0.022 \mathrm{~d}^{-1}$ during the 1995-2005 period at the Bafing Makana stream gauge station [23].

In some basins, dams have been built or are being planned, and they will strongly modify the annual regime and allow hydroelectric power generation, such as in the Konkouré River basin [24].

This paper aims to study the recent evolution of the FD as a natural water tower through the analysis of runoff and depletion coefficients, along other factors such as rainfall and land cover dynamics.

\section{Material and Methods}

This study of the permanency of the Guinean water tower is based on the analysis of the hydrological behavior evolution of 16 basins and sub-basins across these highlands. Basins and their downstream gauging stations are indicated in Figure 5. 


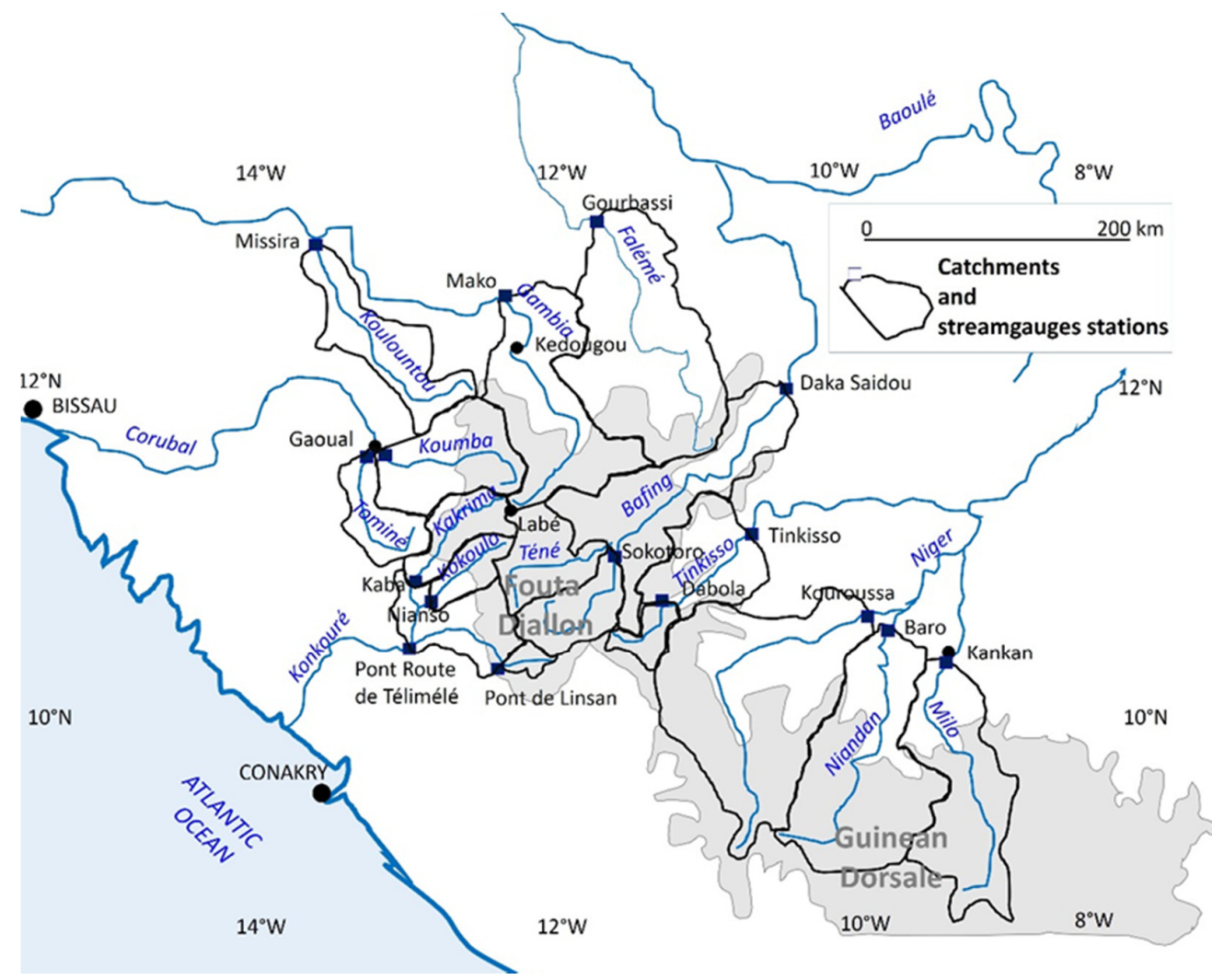

Figure 5. Location of the 16 basins and sub-basins considered in this study.

Excel file in supplementary materials gives the list of the 16 considered basins and the availability of their hydrological data, where vertical black lines separate the three climatic periods: 1947-1969, 1970-1993 and 1994-2019.

Depletion coefficient (or recession coefficient). The recession coefficient is used after the Maillet law (1905) and as cited by Tallaksen (1995) [25] as follows:

$$
\mathrm{Q}_{\mathrm{t}}=\mathrm{Q}_{0} \mathrm{e}^{-\alpha . \mathrm{t}}
$$

$\mathrm{Q}_{\mathrm{t}}=$ discharge at $\mathrm{t}$ time; $\mathrm{Q}_{0}=$ initial discharge at the beginning of the receding waters; $\alpha=$ recession index (= DP). The latter is the inverse of the elapsed time in $\mathrm{d}^{-1}$ and is expressed as

$$
\alpha=-\ln \left(\mathrm{Q}_{\mathrm{t}} / \mathrm{Q}_{0}\right) / \mathrm{t}
$$

The depletion coefficient (DC) used here are the average value of the DC for three durations: one month, two months, and four months (three on the smaller basins). The determined value of the DC is the average value of the DC for each duration around the maximal value of the DC for this duration. The considered period is the one when, on average for the period, the DC is the highest; thus, it is the same for all the years of the period, in the ensuing "Results" part. In a "Supplementary Material" part, we considered, for each station, and for each year, and for three durations (1, 2, and 4 months), the period when the DC reaches its highest value.

\section{Discharges and Runoff Coefficients}

Daily discharge values are provided by the basin agencies (ABN/NBA Niger Basin Authority, for the Niger basin; OMVS-Organisation pour la Mise en Valeur du bassin du fleuve Sénégal- for the Senegal basin; OMVG-Organisation pour la Mise en Valeur du bassin du fleuve Gambie- for the Gambia and Corubal basins) and the National Hydraulic Service of Guinea for the Konkouré basin. 
Rainfall data of 23 stations are provided by SIEREM (Système d'Informations Environnementales sur les Ressources en Eau et leur Modélisation) [26,27], AMMA Catch (AMMA = African Monsoon Muldisciplinary Analysis) (http://www.amma-catch.org/), ANACIM (Agence Nationale de l'Aviation CIvile et de la Météorologie) (Senegalese data), and from the CHIRPS (Climate Hazards Group InfraRed Precipitation with Station data) data system [28] for recent years (since 1980, 1994, or 2000 according to the basins). The CHIRPS products used here have a spatial resolution of $0.25^{\circ}$ and a daily temporal resolution. The covered area is from $50^{\circ} \mathrm{N}$ to $50^{\circ} \mathrm{S}$. They combine satellite data at $0.25^{\circ}$ to soil rainfall data [28]. In order to improve the data accuracy, the CHIRPS data were unskewed again using observed rainfall data for a few stations (see Figure 4): Labé, Koundara, Mamou, Dalaba, Faranah, Tougué, Siguiri, Mali, Gaoual, Conakry, Kindia, Dabola, Kissidougou, Kankan, and Kerouané in Guinea; Kedougou, Tambacounda, and Kolda in Senegal; Kayes, Kenieba, Bafing Makana, Bamako, and Falea in Mali.

\section{Land Use/Land Cover Changes (LULCC) are Determined at Three Scales}

\subsection{At the Regional Scale}

At the regional scale, the tree cover variations between 2000 and 2019 over the 16 basins were extracted from the Global Forest Change (GFC2019) datasets produced by the University of Maryland, based on Landsat 4, 5, 7, and 8 imagery. These provide $30 \mathrm{~m}$ spatial resolution data of tree gains and tree losses compared to land use cover of the year 2000. Cloud-free observations for each pixel, based on quality assessment layers, are used to create composite imagery in bands 3, 4, 5, and 7 during the growing season. Image interpretation relies on a decision tree supervised learning approach and training data, including very high resolution Quickbird imagery as described in Hansen et al. (2013) [29]. Google Earth Engine(C) (Google, Silicon Valley, CA, USA) geoprocessing capabilities [30] were used here to reduce the time to extract and combine pixel data for the 16 basins.

\subsection{At the Basin Scale}

At the basin scale, a special analysis was conducted in the upper Bafing basin. At the Upper Bafing basin scale, changes in vegetation were searched using a time series analysis (TSA) of the normalized difference vegetation index (NDVI) based on a MODIS (Moderate-Resolution Imaging Spectroradiometer; EOS Earth Observing System, NASA, Washington, D.C., USA) (MODQ13 dataset (250 m resolution; 16 days temporal resolution; from February 2000 to February 2020). Mann-Kendall's tau test is an efficient trend detection method [31] and has been used for this data type for other regions of western Africa [32-34]. Mann-Kendall's tau test can be submitted to null hypothesis ( $P$ value) testing as the data come from a population with independent realizations and are identically distributed. A significance at 0.001 has been retained for this paper meaning that a sample as extreme as that observed would occur 1 time in 1000 if the null hypothesis is true.

\subsection{At the Local Scale}

At the local scale, some small wetlands of river sources are compared in the central area of the FD. Here, we compare the current status (via Google Earth@) images; Google, Silicon Valley, CA, USA) with aerial imagery acquired by the IGN (Institut National de l'Information Géographique et Forestière, Saint Mandé, France) 1953 mission over West Africa.

\section{Results}

\subsection{Changes of Depletion Coefficients}

Figure 6a-e and Table 2A-D gather the results about changes in the DC (depletion coefficient). In these figures, the DC is calculated for a period of four months (and three months for the two Sokotoro and Pont de Linsan smaller basins) for each year on the same date, i.e., the average date of the 
maximum depletion of the discharge (in the Supplementary Materials, Figures S1a,b-S16a,b illustrate the evolution of the DC at the highest yearly depletion rate of each year).

\section{Konkouré River basin}

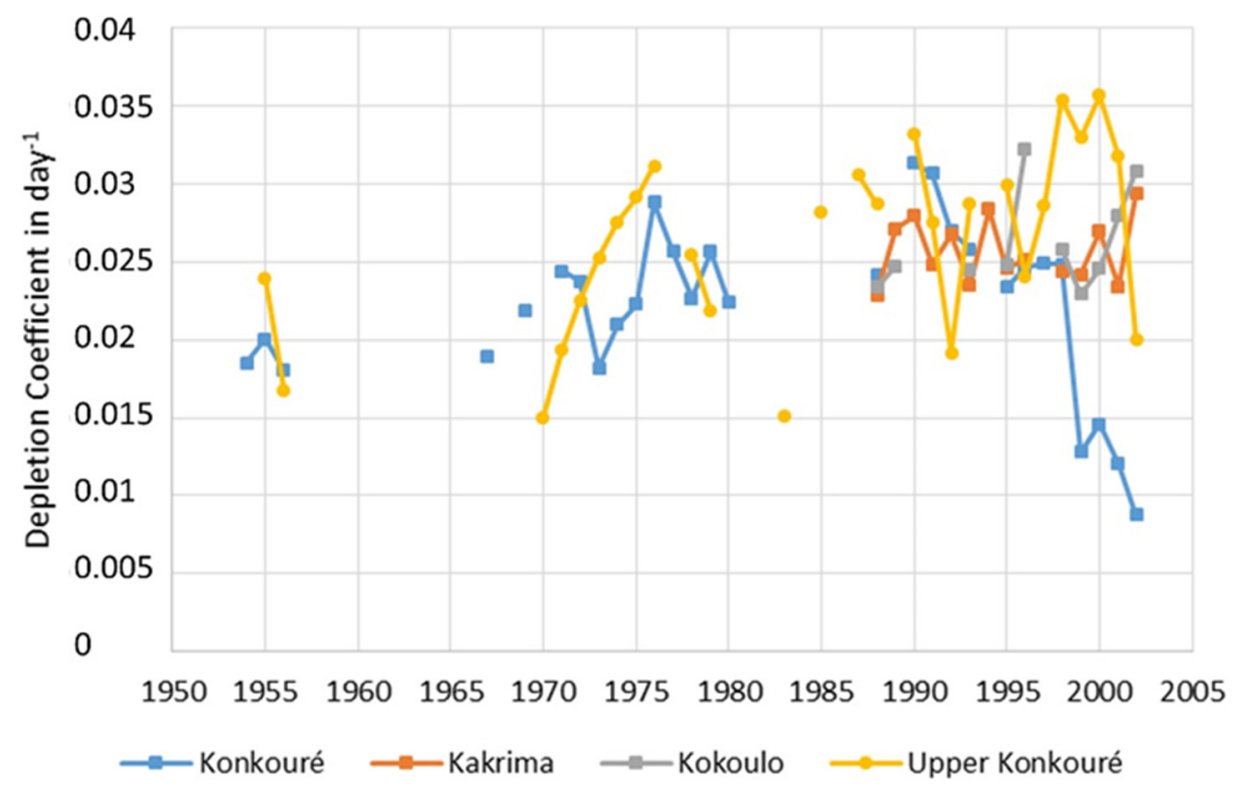

(a)

\section{Corubal/Koumba/Koliba River Basin}

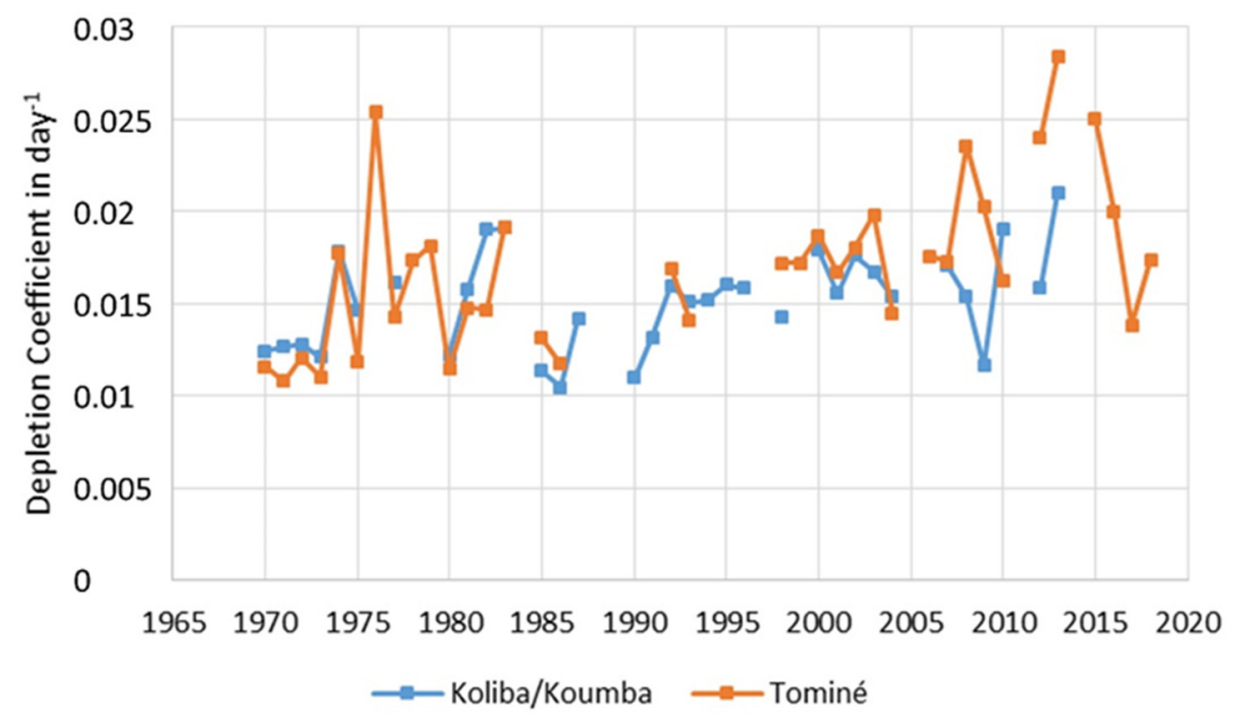

(b)

Figure 6. Cont. 


\section{Gambia River Basin}

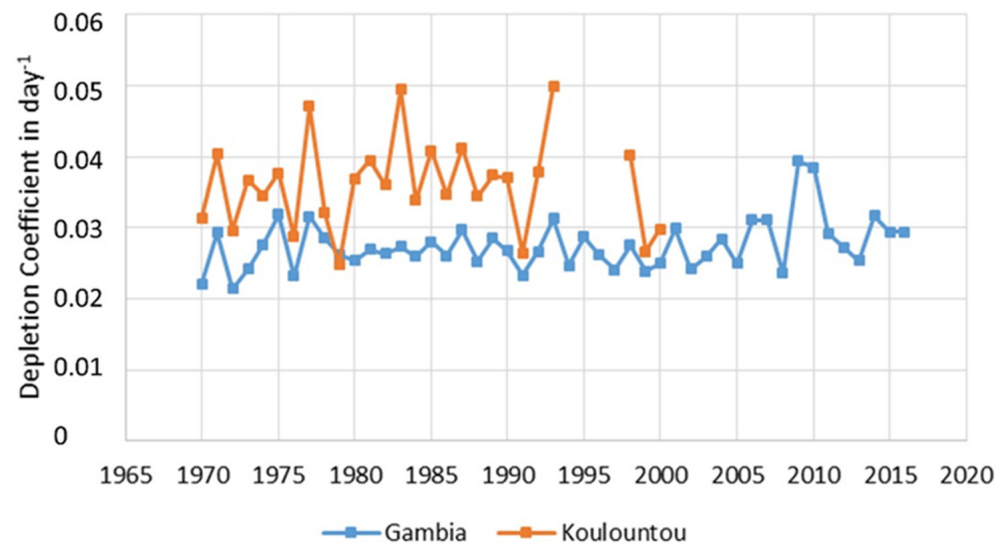

(c)

Senegal River Basin

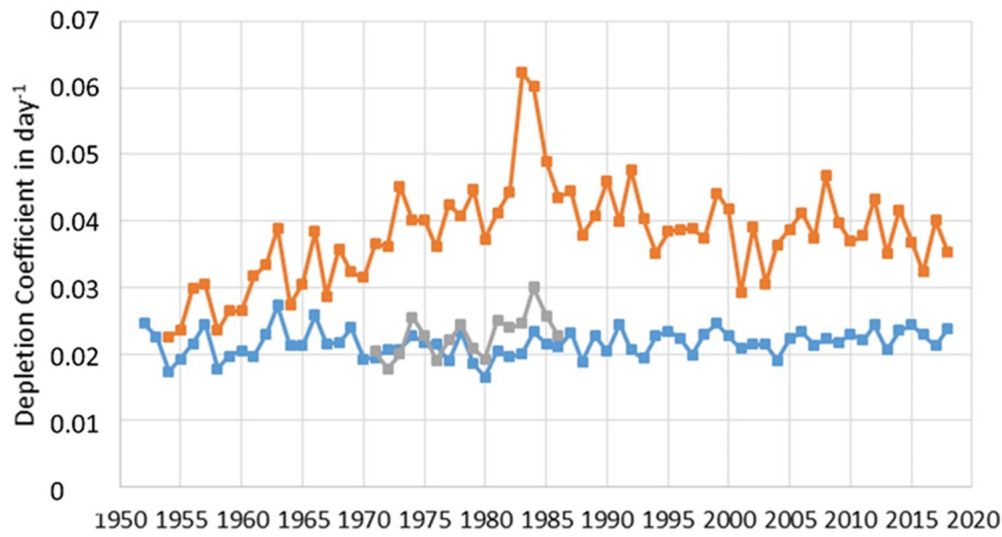

$\because$ Bafing $\longrightarrow$ Falémé $\because$ Upper Bafing

(d)

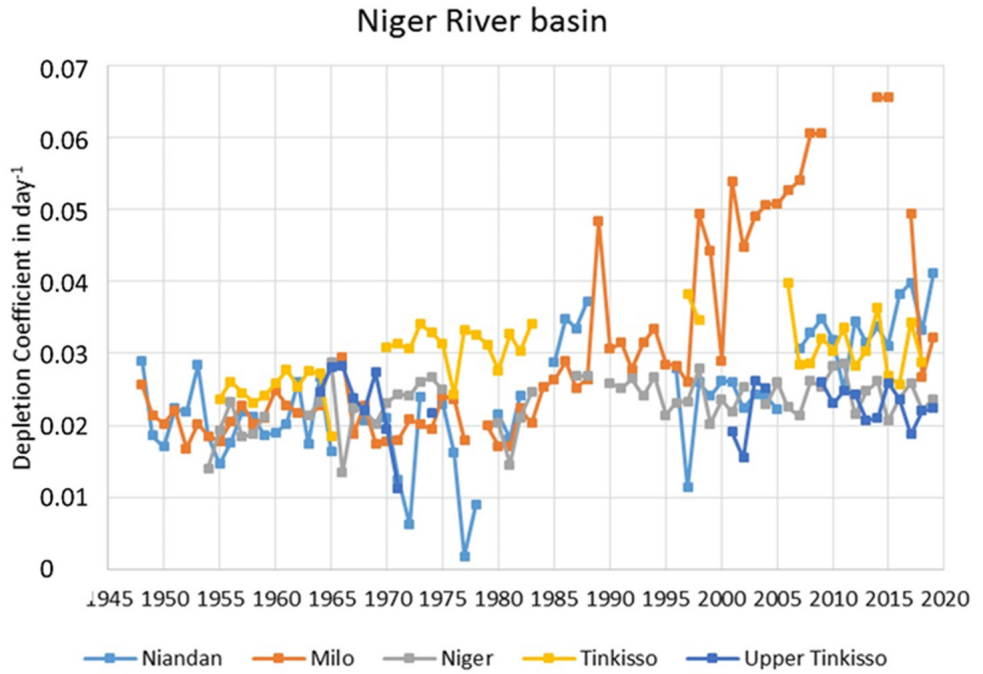

(e)

Figure 6. Dynamic of depletion coefficients for the period 1947-2018, by basin; (a) Konkouré River basin; (b) Koliba/Tominé/Corubal River basin; (c) Gambia River basin; (d) Senegal River basin; (e) Niger River basin. 
Table 2. Depletion coefficient by basins, by periods, and for different durations.

\begin{tabular}{|c|c|c|c|c|c|c|c|c|c|c|c|c|c|}
\hline \multirow[t]{2}{*}{$\mathbf{A}$} & \multirow[t]{2}{*}{ Decreasing } & \multirow[t]{2}{*}{$\mathrm{DC}$} & & \multicolumn{3}{|c|}{4 Months Depletion Coef } & \multicolumn{3}{|c|}{2 Months Depletion Coef } & \multicolumn{3}{|c|}{1 Month Depletion Coef } & \multirow{2}{*}{$\begin{array}{c}\text { Yearly } \\
\begin{array}{c}\text { Deforestation } \\
\%\end{array}\end{array}$} \\
\hline & & & & Mean 1947-70 & Mean 71-93 & Mean 94-2019 & Mean 1947-70 & Mean 71-93 & Mean 94-2019 & Mean 1947-70 & Mean 71-93 & Mean 94-2019 & \\
\hline Senegal & Gourbassi & Faleme & $\begin{array}{l}\text { coef } \\
\text { day }\end{array}$ & $\begin{array}{c}0.0339 \\
\text { 28-November }\end{array}$ & $\begin{array}{c}0.0460 \\
25-\text { November }\end{array}$ & $\begin{array}{c}0.0412 \\
\text { 1-December }\end{array}$ & $\begin{array}{c}0.0433 \\
\text { 27-October }\end{array}$ & $\begin{array}{c}0.0533 \\
\text { 3-November }\end{array}$ & $\begin{array}{l}0.0465 \\
3 \text {-Nov }\end{array}$ & $\begin{array}{c}0.0550 \\
\text { 18-October }\end{array}$ & $\begin{array}{c}0.0622 \\
\text { 23-October }\end{array}$ & $\begin{array}{c}0.0554 \\
\text { 18-October }\end{array}$ & 0.099 \\
\hline Senegal & $\begin{array}{l}\text { Daka } \\
\text { Saidou }\end{array}$ & Bafing & coef & 0.0238 & 0.0243 & 0.0237 & 0.0298 & 0.0321 & 0.0317 & 0.0352 & 0.0395 & 0.0392 & 0.197 \\
\hline Niger & Dabola & Tinkisso & $\begin{array}{l}\text { day } \\
\text { coef } \\
\text { day }\end{array}$ & $\begin{array}{c}\text { 29-November } \\
0.0264 \\
\text { 3-December }\end{array}$ & $\begin{array}{c}\text { 8-November } \\
0.0228 \\
\text { 20-November }\end{array}$ & $\begin{array}{l}\text { 3-December } \\
0.0252 \\
\text { 9-December }\end{array}$ & $\begin{array}{c}\text { 7-November } \\
0.0381 \\
\text { 4-November }\end{array}$ & $\begin{array}{c}\text { 5-November } \\
0.0366 \\
\text { 25-October }\end{array}$ & $\begin{array}{c}\text { 17-November } \\
0.0351 \\
15 \text {-November }\end{array}$ & $\begin{array}{c}\text { 5-November } \\
0.0485 \\
\text { 27-October }\end{array}$ & $\begin{array}{c}\text { 18-October } \\
0.0456 \\
17-\text { October }\end{array}$ & $\begin{array}{c}\text { 11-November } \\
0.0424 \\
\text { 2-November }\end{array}$ & 0.873 \\
\hline \multirow[t]{2}{*}{ B } & Stabilized & DC & & $\begin{array}{l}4 \text { Months } \\
\text { Depletion } \\
\text { Coef }\end{array}$ & $\begin{array}{l}2 \text { Months } \\
\text { Depletion } \\
\text { Coef }\end{array}$ & $\begin{array}{l}1 \text { Month } \\
\text { Depletion } \\
\text { Coef }\end{array}$ & Yearly & & & & & & \\
\hline & & & & Mean 1947-70 & Mean 71-93 & Mean 94-2019 & Mean 1947-70 & Mean 71-93 & Mean 94-2019 & Mean 1947-70 & Mean 71-93 & Mean 94-2019 & $\begin{array}{c}\text { Deforestation } \\
\%\end{array}$ \\
\hline Gambia & Missirah & \multicolumn{2}{|c|}{ Koulountou coef } & & $\begin{array}{c}0.0407 \\
\text { 21-November }\end{array}$ & $\begin{array}{c}0.0394 \\
\text { 3-December }\end{array}$ & & $\begin{array}{c}0.0434 \\
6-N a v e m b e r\end{array}$ & $\begin{array}{c}0.0443 \\
15-N \text { remer }\end{array}$ & & $\begin{array}{c}0.0525 \\
24-\text { O }\end{array}$ & $\begin{array}{c}0.0625 \\
\text { 8-Novemer }\end{array}$ & 0.339 \\
\hline Gambia & Mako & Gambia & coef & & $\begin{array}{l}0.0294 \\
29-\text { November }\end{array}$ & $\begin{array}{c}0.0308 \\
4-N o y e m b e r\end{array}$ & & 0.0381 & $\begin{array}{l}0.0401 \\
5-\text { Noyemer }\end{array}$ & & $\begin{array}{l}0.0485 \\
22-\text { Octor }\end{array}$ & $\begin{array}{l}0.0500 \\
29-O c t o b r\end{array}$ & 0.427 \\
\hline Corubal & Gaoual K & $\begin{array}{l}\text { Koumba } \\
\text { (Koliba) }\end{array}$ & $\begin{array}{l}\text { coef } \\
\text { day }\end{array}$ & & $\begin{array}{c}0.0201 \\
\text { 30-November }\end{array}$ & $\begin{array}{c}0.0197 \\
\text { 9-December }\end{array}$ & & $\begin{array}{c}0.0284 \\
\text { 30-October }\end{array}$ & $\begin{array}{l}0.0267 \\
\text { 9-November }\end{array}$ & & $\begin{array}{c}0.0388 \\
\text { 31-October }\end{array}$ & $\begin{array}{c}0.0371 \\
\text { 14-November }\end{array}$ & 0.836 \\
\hline Senegal & Sokotoro & Bafing & $\begin{array}{l}\text { coef } \\
\text { day }\end{array}$ & & $\begin{array}{c}0.0269 \\
\text { 27-November }\end{array}$ & & & $\begin{array}{c}0.0314 \\
\text { 16-November }\end{array}$ & & & $\begin{array}{l}0.0403 \\
30-\text { Oct }\end{array}$ & & 2.229 \\
\hline Niger & Kouroussa & Niger & coef & $\begin{array}{c}0.0249 \\
\text { day }\end{array}$ & $\begin{array}{c}0.0269 \\
\text { 27-December }\end{array}$ & $\begin{array}{c}0.0271 \\
\text { 18-December }\end{array}$ & $\begin{array}{c}0.0300 \\
\text { 28-December }\end{array}$ & $\begin{array}{c}0.0321 \\
\text { 25-December }\end{array}$ & $\begin{array}{c}0.0312 \\
\text { 14-December }\end{array}$ & $\begin{array}{c}0.0355 \\
\text { 1-December }\end{array}$ & $\begin{array}{c}0.0383 \\
\text { 26-November }\end{array}$ & $\begin{array}{c}0.0366 \\
\text { 10-December }\end{array}$ & $\begin{array}{c}0.936 \\
\text { 21-November }\end{array}$ \\
\hline C & Increasing & DC & $<20 \%$ & $\begin{array}{l}4 \text { Months } \\
\text { Depletion } \\
\text { Coef }\end{array}$ & $\begin{array}{l}2 \text { Months } \\
\text { Depletion } \\
\text { Coef }\end{array}$ & $\begin{array}{c}1 \text { Month } \\
\text { Depletion } \\
\text { Coef }\end{array}$ & Yearly & & & & & & \\
\hline Ddef & & & & Mean 1947-70 & Mean 71-93 & Mean 94-2019 & Mean 1947-70 & Mean 71-93 & Mean 94-2019 & Mean 1947-70 & Mean 71-93 & Mean 94-2019 & $\begin{array}{c}\text { Deforestation } \\
\%\end{array}$ \\
\hline Konkouré & Nianso & Kokoulo & $\begin{array}{l}\text { coef } \\
\text { day }\end{array}$ & & $\begin{array}{c}0.0297 \\
\text { 30-November }\end{array}$ & $\begin{array}{c}0.0305 \\
\text { 12-December }\end{array}$ & & $\begin{array}{c}0.0281 \\
\text { 14-November }\end{array}$ & $\begin{array}{c}0.0334 \\
\text { 24-November }\end{array}$ & & $\begin{array}{c}0.0368 \\
\text { 1-November }\end{array}$ & $\begin{array}{c}0.0418 \\
\text { 19-November }\end{array}$ & 1.858 \\
\hline Konkouré & Kaba & Kakrima & coef & & $\begin{array}{c}0.0278 \\
\text { 9-December }\end{array}$ & $\begin{array}{l}0.0295 \\
\text { 2-Decer }\end{array}$ & & $\begin{array}{l}0.0320 \\
09-\text { November }\end{array}$ & $\begin{array}{l}\text { 24-1-0344 } \\
0.034 \\
17-N o v e m b e r\end{array}$ & & $\begin{array}{l}0.0399 \\
15-N o y e m b e r\end{array}$ & $\begin{array}{c}0.0400 \\
8 \text {-Noyemer }\end{array}$ & 1.724 \\
\hline Corubal & Gaoual T & Tominé & coef & & 0.0201 & 0.0241 & & $\begin{array}{c}0.0279 \\
\text { 30-November }\end{array}$ & $\begin{array}{l}0.0318 \\
\text { 4-December }\end{array}$ & & $\begin{array}{l}0.0393 \\
\text { 30-October }\end{array}$ & $\begin{array}{c}0.0428 \\
\text { 6-November }\end{array}$ & 2.273 \\
\hline
\end{tabular}


Table 2. Cont

\begin{tabular}{|c|c|c|c|c|c|c|c|c|c|c|c|c|c|}
\hline D & Increasing & DC & $>20 \%$ & $\begin{array}{l}4 \text { Months } \\
\text { Depletion } \\
\text { Coef }\end{array}$ & $\begin{array}{l}2 \text { Months } \\
\text { Depletion } \\
\text { Coef }\end{array}$ & $\begin{array}{l}1 \text { Month } \\
\text { Depletion } \\
\text { Coef }\end{array}$ & Yearly & & & & & & \\
\hline & & & & mean $1947-70$ & mean 71-93 & mean 94-2019 & mean $1947-70$ & mean 71-93 & mean 94-2019 & mean $1947-70$ & mean 71-93 & mean 94-2019 & $\begin{array}{c}\text { Deforestation } \\
\%\end{array}$ \\
\hline Niger & Tinkisso & Tinkisso & coef & $\begin{array}{r}0.0269 \\
\text { 18-Decem }\end{array}$ & $\begin{array}{r}0.0333 \\
\text { 21-Deceml }\end{array}$ & $\begin{array}{c}0.0365 \\
\text { 1-Jan }\end{array}$ & $\begin{array}{r}0.0342 \\
\text { 24-Novem }\end{array}$ & $\begin{array}{r}0.0374 \\
\text { 9-Novem }\end{array}$ & $\begin{array}{r}0.0390 \\
\text { 2-Decemk }\end{array}$ & $\begin{array}{r}0.0459 \\
\text { 14-Novem }\end{array}$ & $\begin{array}{r}0.0465 \\
\text { 2-Novem }\end{array}$ & 0.0505 & 0.235 \\
\hline Niger & Baro & Niandan & coef & & & & & $\begin{array}{l}\text { 19-November } \\
0.0325 \\
\text { 5-December }\end{array}$ & $\begin{array}{c}\text { 2-Decemorer } \\
0.0383 \\
\text { 27-December }\end{array}$ & $\begin{array}{c}\text { 14-November } \\
0.0356 \\
\text { 30-November }\end{array}$ & $\begin{array}{l}\text { 2-November } \\
0.0393 \\
\text { 25-November }\end{array}$ & $\begin{array}{c}\text { 19-November } \\
0.0443 \\
\text { 24-December }\end{array}$ & 0.626 \\
\hline Niger & Kankan & Milo & $\begin{array}{l}\text { coef } \\
\text { day }\end{array}$ & $\begin{array}{c}0.0227 \\
\text { 8-December }\end{array}$ & $\begin{array}{c}0.0256 \\
\text { 6-December }\end{array}$ & $\begin{array}{c}0.0321 \\
\text { 15-November }\end{array}$ & $\begin{array}{c}0.0285 \\
\text { 16-November }\end{array}$ & $\begin{array}{c}0.0310 \\
11 \text {-November }\end{array}$ & $\begin{array}{c}0.0419 \\
\text { 14-November }\end{array}$ & $\begin{array}{c}0.0347 \\
\text { 2-November }\end{array}$ & $\begin{array}{l}0.0397 \\
\text { 9-November }\end{array}$ & $\begin{array}{c}0.0517 \\
\text { 11-November }\end{array}$ & 0.634 \\
\hline Konkouré & $\begin{array}{c}\text { Pt Rte } \\
\text { Télimélé }\end{array}$ & Konkouré & coef & 0.0132 & 0.0212 & 0.0245 & 0.0153 & 0.0252 & 0.0268 & 0.0191 & 0.0281 & 0.0359 & 0.881 \\
\hline & & & day & 7-January & 26-December & 13-December & 8-December & 3-December & 29-November & 26-November & 19-November & 11-November & \\
\hline Konkouré & $\begin{array}{c}\text { Pt de } \\
\text { Linsan }\end{array}$ & Upper K. & $\begin{array}{l}\text { coef } \\
\text { day }\end{array}$ & $\begin{array}{c}0.0234 \\
\text { 7-November }\end{array}$ & $\begin{array}{c}0.0303 \\
\text { 14-November }\end{array}$ & $\begin{array}{c}0.0334 \\
\text { 22-November }\end{array}$ & $\begin{array}{c}0.0294 \\
\text { 22-October }\end{array}$ & $\begin{array}{c}0.0343 \\
\text { 6-November }\end{array}$ & $\begin{array}{c}0.0376 \\
\text { 7-November }\end{array}$ & $\begin{array}{c}0.0365 \\
\text { 23-October }\end{array}$ & $\begin{array}{c}0.0473 \\
\text { 31-October }\end{array}$ & $\begin{array}{c}0.0460 \\
\text { 11-November }\end{array}$ & 3.731 \\
\hline
\end{tabular}

Basins are classified into four classes, according to the temporal evolution of the depletion coefficient (DC): decreasing, stabilized, increasing until 20\% from the first to third period, and increasing above 20\%. Deforestation is here one of the tree cover variations between 2000 and 2019 over the 16 basins, using data of Maryland University (the GFC2019), according to the method proposed by [29] Hansen et al. (2013). 
Data covering the 1947-2019 timeline was divided into three periods, based on previous segmentation by several authors ([35-38]):

- $\quad$ the first one is the 'hyper humid' 1947-1969 period, when rainfall was significantly higher than the long-term average across the whole of West Africa.

- $\quad$ the second period is the well-known "Great Drought" of West Africa (1970-1993). The rainfall decreased significantly in 1968, but we arbitrarily made the second period begin in 1970 because a significant number of stream gauge stations have data starting from 1970. The drought is considered to last until 1993.

- the last period spans the years 1994-2019. The year 1994 is when annual rainfall again reached again its long-term mean value. During this period, rainfall is approximately of the long-term trend.

Rainfall predictions in West Africa indicate a regional increase in rainfall during the ongoing 21st century due to the activation of monsoons as a result of the increase in the difference between the continental temperature and SST (sea surface $\mathrm{T}^{\circ}$ ) [39]. However, locally, in the western part of West Africa, rainfall is expected to decrease significantly after 2030 or 2035 (Senegambia, Mauritania, and western Mali), while further south, an increase in ATR (annual total rainfall) across most of the Guinean territory is expected [40,41].

The dynamics of the depletion coefficients (see Figure 6a-e and Table 2A-D; see also the Supplementary Materials) shows that:

- the evolution through the three periods is not easy to observe for each basin due to the lack of data (some of the data begins in 1970). The only basins where an analysis over the entire period of 1950-2019 is possible are the largest ones (Senegal and Niger Rivers).

From period 1 to period 2:

- $\quad$ an increase in the DC between period 1 and period 2 is clearly observed in the Upper Niger (at Kouroussa, where it begins in 1965, and at Tinkisso, where an increase in the DC appeared after 1970) and in the Senegal basin. This is clear in the Faleme basin (and probably in the upper Bafing at Sokotoro, though data are lacking). This increase is also observed in the Corubal basin (but particularly over the first drought period, 1970-1975). Despite the lack of data, such a trend also appears in the Gambia River basins (Mako and Missira stream gauges, the second one showing much higher variability). However, it is very difficult to observe this increasing trend in the Konkouré basin, and clearly, the Bafing basin at Daka Saidou does not show any such trends across all available observations.

- $\quad$ only the Niandan at Baro and, to a lesser extent, the upper Tinkisso at Dabola (Figure 5e, but with very limited data) showed a decrease in the DC.

From period 2 to period 3:

- $\quad$ except the Bafing at Daka Saidou, the three main 'Sudano-Sahelian' rivers (the Gambia at Mako, the Niger at Kouroussa, as well as the Faleme at Gourbassi) show a decrease in the DC between the dry 1970-1993 period and the following 1994-2019 period. The DC of Koliba Koumba River also decreased slowly after the drought.

- for 8 out of the 16 basins, a decrease (3) or a stabilization (5) in the DC is observed after 1994 and the rainfall recovery. For the other eight stations, an increase in the DC is ongoing. The increase over the whole period is lower than $20 \%$ in three basins (Table 2C) and higher than $20 \%$ in five others (Table 2D).

- $\quad$ some basins (Niandan, Milo, Gambia, Tominé) show a marked increase in the DC at the end of the last period: in all of these basins, depletion was higher during the 2005-2015 period than during the Great Drought period. 
- $\quad$ Extreme values can be observed in the last years (e.g., in the Milo basin), and in 1983-1984 in the Faleme. As described by Olivry (1986), this happens when the higher value of depletion coefficient occurs when the river dries up completely. Consequently, the DC becomes in some cases the drying up coefficient.

General observations

- in some basins, the depletion coefficient can be different depending on the method selected or on the context.

- $\quad$ except the increase in the DC during the drought and decrease after the drought in the large basins, there are no general trends to detect, reflecting great variability across the basins.

- overall, contrary to previous observations by Descroix [5] and Descroix et al. [42], which were based on the behavior of the Upper Niger basin tributaries, there is not a general trend of increasing DC, which could demonstrate a general reduction in the soil water-holding capacity. This trend only appears in the Konkouré basin and in the Milo and Niandan basins.

In Table 2, the last column provides the evolution of forest cover by basin based on the Global Forest Change (GFC2019) methodology.

The day when the maximal depletion occurs seems to follow a general behavior, occurring earlier when the depletion coefficient increases (mostly during the drought), later during the first period (yet with numerous gaps in the data), and overall during the last period. This follows an intuitive pattern, with a depletion stage of the river starting later when discharges are abundant and earlier during the dry years. The exception is the case of the Konkouré basin, where the upper basin (Pont de Linsan station) is the one wherein the discharge has decreased the most. The same evolution is shown at the downstream station "Pont de la route de Télimélé", but this station has been influenced since 1999 by the filling and management of the Garafiri dam. This is why its DC decreased strongly after 1999.

\subsection{Evolution of Runoff Coefficients}

Table 3 gathers the basins' hydrological characteristics and their changes over the three determined periods: discharge $(\mathrm{Q})$, specific discharge $(\mathrm{SD})$, runoff coefficient $(\mathrm{RC})$, as well as the maximal discharge of the year and its day of occurrence. 
Table 3. Hydrological characteristics of the 16 classified basins.

\begin{tabular}{|c|c|c|c|c|c|c|c|c|c|c|c|c|c|c|c|}
\hline \multirow[t]{2}{*}{ B } & \multicolumn{3}{|l|}{ Class B } & \multicolumn{3}{|c|}{ Discharge $\mathrm{m}^{3} \cdot \mathrm{s}^{-1}$} & \multicolumn{3}{|c|}{ Specific Discharge $1 . \mathrm{s}^{-1} \cdot \mathrm{km}^{-2}$} & \multicolumn{3}{|c|}{$\begin{array}{c}\text { Runoff } \\
\text { Coefficient }\end{array}$} & \multicolumn{3}{|c|}{ Max Daily Discharge/+ Day } \\
\hline & Station & Basin & Area $\mathrm{km}^{2}$ & $47-70$ & 71-93 & 94-2019 & $47-70$ & $71-93$ & 94-2019 & $47-70$ & 71-93 & 94-19 & $47-70$ & 71-93 & 94-2019 \\
\hline Senegal & $\begin{array}{l}\text { Daka } \\
\text { Saidou }\end{array}$ & Bafing & 15700 & 306.6 & 182.4 & 225.9 & 19.5 & 11.6 & 14.4 & 0.390 & 0.264 & 0.310 & $\begin{array}{c}1750 / 16 \\
\text { September }\end{array}$ & $\begin{array}{l}\text { 1074/29 } \\
\text { August }\end{array}$ & $\begin{array}{c}1363 / 4 \\
\text { September }\end{array}$ \\
\hline Senegal & Sokotoro & $\begin{array}{l}\text { Up } \\
\text { Bafing }\end{array}$ & 1750 & & 29.6 & & & 16.9 & & & 0.354 & & & $\begin{array}{c}136 / 5 \\
\text { September }\end{array}$ & \\
\hline Niger & Tinkisso & Tinkisso & 6370 & 89.0 & 55.0 & 87.1 & 14.0 & 8.6 & 13.7 & 0.296 & 0.197 & 0.308 & $\begin{array}{c}\text { 337/31 } \\
\text { August }\end{array}$ & $\begin{array}{c}244 / 19 \\
\text { September }\end{array}$ & $\begin{array}{c}332 / 20 \\
\text { September }\end{array}$ \\
\hline Niger & Dabola & $\begin{array}{c}\text { Up } \\
\text { Tinkisso }\end{array}$ & 1260 & 14.9 & 14.1 & 14.5 & 11.8 & 11.2 & 11.5 & 0.244 & 0.226 & 0.242 & $\begin{array}{c}67.1 / 4 \\
\text { September } \\
1188 / 29\end{array}$ & $\begin{array}{c}65.1 / 5 \\
\text { September } \\
728 / 15\end{array}$ & $\begin{array}{c}64.2 / 21 \\
\text { September } \\
840 / 25\end{array}$ \\
\hline Niger & Kouroussa & Niger & 16560 & 256.0 & 165.0 & 181 & 15.5 & 10.0 & 10.9 & 0.286 & 0.201 & 0.212 & $\begin{array}{l}1188 / 29 \\
\text { September }\end{array}$ & September & September \\
\hline Niger & Baro & Niandan & 12770 & 274.2 & 205.2 & 205.4 & 21.5 & 16.1 & 16.1 & 0.348 & 0.281 & 0.284 & $\begin{array}{c}1192 / 21 \\
\text { September }\end{array}$ & $\begin{array}{c}865 / 13 \\
\text { September }\end{array}$ & $\begin{array}{c}922 / 7 \\
\text { September }\end{array}$ \\
\hline Niger & Kankan & Milo & 9620 & 206.4 & 149.4 & 144.9 & 21.0 & 15.5 & 15.1 & 0.349 & 0.284 & 0.262 & $\begin{array}{c}771 / 18 \\
\text { September }\end{array}$ & $\begin{array}{c}665 / 10 \\
\text { September }\end{array}$ & $\begin{array}{c}712 / 19 \\
\text { September }\end{array}$ \\
\hline \multirow[t]{2}{*}{ A } & Class A & & & $\begin{array}{c}\text { Discharge } \\
\mathrm{m}^{3} \cdot \mathrm{s}^{-1}\end{array}$ & $\begin{array}{c}\text { Specific } \\
\text { Discharge } \\
1 . \mathrm{s}^{-1} \cdot \mathrm{km}^{-2}\end{array}$ & $\begin{array}{c}\text { Runoff } \\
\text { Coefficient }\end{array}$ & $\begin{array}{c}\text { Max Daily } \\
\text { Discharge/+ } \\
\text { Day }\end{array}$ & & & & & & & & \\
\hline & Station & Basin & Area $\mathrm{km}^{2}$ & $47-70$ & 71-93 & 94-2019 & $47-70$ & 71-93 & 94-2019 & $47-70$ & 71-93 & 94-2019 & $47-70$ & 71-93 & 94-2019 \\
\hline Senegal & Gourbassi & Faleme & 17100 & 166.5 & 64.8 & 100.4 & 9.7 & 3.8 & 5.9 & 0.225 & 0.102 & 0.149 & $\begin{array}{c}1322 / 1 \\
\text { January }\end{array}$ & $\begin{array}{c}746 / 6 \\
\text { September }\end{array}$ & $\begin{array}{c}977 / 10 \\
\text { September }\end{array}$ \\
\hline Gambia & Mako & Gambia & 10540 & & 79.3 & 116.6 & & 7.6 & 11.2 & & 0.184 & 0.247 & & $\begin{array}{c}69 / 6 \\
\text { September }\end{array}$ & September \\
\hline Gambia & Missirah & Koulountou & 6200 & & 27.3 & 32.9 & & 4.4 & 5.3 & & 0.118 & 0.131 & & $\begin{array}{c}170 / 17 \\
\text { September } \\
\end{array}$ & $\begin{array}{c}209 / 11 \\
\text { September } \\
\end{array}$ \\
\hline \multirow[t]{2}{*}{ C } & Class C & & & $\begin{array}{c}\text { Discharge } \\
\mathrm{m}^{3} \cdot \mathrm{s}^{-1}\end{array}$ & $\begin{array}{c}\text { Specific } \\
\text { Discharge } \\
1 \cdot \mathrm{s}^{-1} \cdot \mathrm{km}^{-2}\end{array}$ & $\begin{array}{c}\text { Runoff } \\
\text { Coefficient }\end{array}$ & $\begin{array}{c}\text { Max Daily } \\
\text { Discharge/+ } \\
\text { Day }\end{array}$ & & & & & & & & \\
\hline & Station & Basin & Area $\mathrm{km}^{2}$ & $47-70$ & 71-93 & 94-2019 & $47-70$ & 71-93 & 94-2019 & $47-70$ & 71-93 & 94-2019 & $47-70$ & 71-93 & 94-2019 \\
\hline Konkouré & $\begin{array}{l}\text { Ptde } \\
\text { Linsan }\end{array}$ & Konkouré & 402 & 17.5 & 13.1 & 12.2 & 43.5 & 32.5 & 30.5 & 0.655 & 0.528 & 0.476 & $\begin{array}{c}113 / 20 \\
\text { August }\end{array}$ & $\begin{array}{l}88.9 / 26 \\
\text { August }\end{array}$ & $\begin{array}{c}93.3 / 6 \\
\text { September }\end{array}$ \\
\hline Konkouré & Nianso & Kokoulo & 2260 & & 60.8 & 62.1 & & 26.9 & 27.5 & & 0.486 & 0.439 & & $\begin{array}{l}533 / 28 \\
\text { August }\end{array}$ & $\begin{array}{c}441 / 29 \\
\text { August }\end{array}$ \\
\hline Konkouré & Kaba & Kakrima & 3190 & & 72.4 & 77.6 & & 22.7 & 24.3 & & 0.407 & 0.392 & & $\begin{array}{l}468 / 27 \\
\text { August }\end{array}$ & $\begin{array}{c}496 / 26 \\
\text { August }\end{array}$ \\
\hline Konkouré & $\begin{array}{c}\mathrm{Pt} \\
\text { Télimélé }\end{array}$ & Konkouré & 10210 & 427.4 & 255.0 & 262.0 & 41.9 & 25.0 & 25.7 & 0.604 & 0.410 & 0.401 & $\begin{array}{l}\text { 1971/19 } \\
\text { August }\end{array}$ & $\begin{array}{l}1409 / 23 \\
\text { August }\end{array}$ & $\begin{array}{c}1422 / 5 \\
\text { September }\end{array}$ \\
\hline Corubal & $\begin{array}{l}\text { Gaoual } \\
\text { T }\end{array}$ & Tominé & 3300 & & 98.1 & 124.2 & & 29.7 & 37.6 & & 0.471 & 0.529 & & $\begin{array}{l}565 / 30 \\
\text { August }\end{array}$ & $\begin{array}{c}642 / 13 \\
\text { September }\end{array}$ \\
\hline Corubal & $\begin{array}{c}\text { Gaoual } \\
\mathrm{K}\end{array}$ & Koumba & 6200 & & 174.1 & 201.5 & & 28.5 & 33.0 & & 0.500 & 0.533 & & $\begin{array}{c}879 / 6 \\
\text { September }\end{array}$ & $\begin{array}{c}972 / 8 \\
\text { September }\end{array}$ \\
\hline
\end{tabular}

Basins are classified according to the specific discharges (SD) and runoff coefficient (RC). Class A: SD below 12, RC below 0.2. Class B: SD ranging from 12 to $22, \mathrm{RC}$ ranging from 0.2 to 0.4 . Class C: SD above 22, RC above 0.4 . 
The general dynamic follows the rainfall trends with a decrease in streamflow between the first period (1947-1969) and the second (1970-1993), followed by an increase in discharge between the second period and the third (1994-2019). Yet two important exceptions have to be highlighted:

- the Konkouré basin, where runoff did not rise again after the dry period, but in this basin, data is not available after 2002, preventing analysis of the long term and obscuring a possible recovery of streamflows. However, since rainfall increased significantly between period 2 and 3 , a decrease in the runoff coefficient is noticed.

- $\quad$ the Upper Niger basin where runoff increased only in the Tinkisso basin (except for its upper part) over the last period.

This could be explained by a longer time being necessary to refill the natural water reservoir.

The maximum daily discharge observed each year shows approximately the same trends (Table 3, last column): the day when this maximum is observed is in most cases later when the discharge increases and earlier when streamflows are low.

\subsection{Any Explanation from the LULCC?}

The analysis of the relationship between, on the one hand, runoff and depletion coefficients and, on the other hand, land use/land cover changes (LULCC) during the period of 2000-2019 is made with the data provided by the $30 \mathrm{~m}$ Global Forest Change datasets [29] (Figures 7 and 8). Considering no local field validation has been done and the inconsistencies in some results, the forest evolution shown here must be considered as relative and not as absolute.

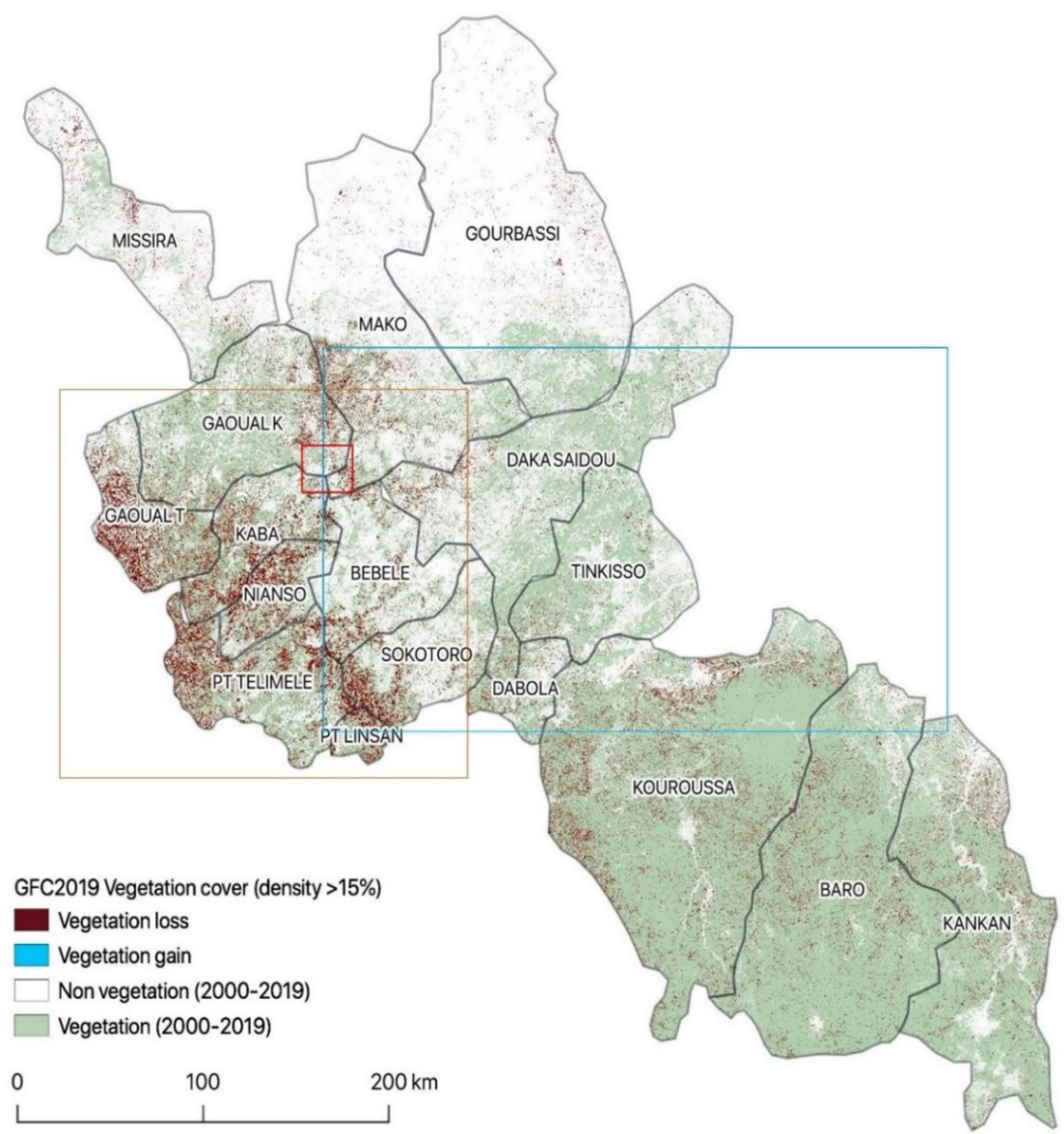

Figure 7. Vegetation (forest density higher than 15\%) in 2000 and 2019 and vegetation loss and gain (GFC (Global Forest Change) product [29]), for the 16 basins. The empty brown rectangle is the area covered by the map in Figure 8. 


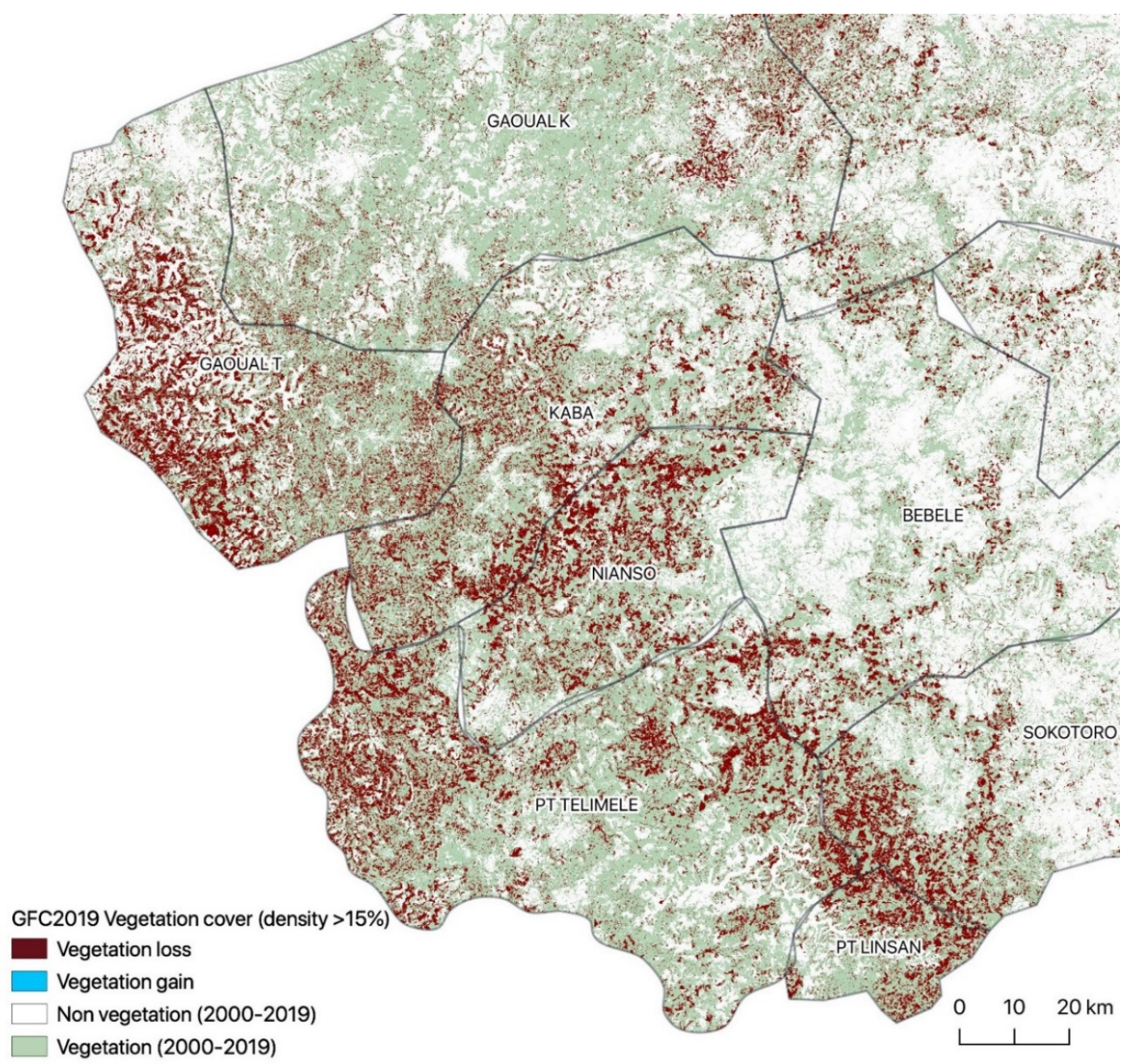

Figure 8. Vegetation (density higher than 15\%) in 2000 and 2019 and vegetation losses and gains (2001-2019) (GFC product, [29]) for the western basins of the FD, where vegetation losses are the highest. The area represented is the one of the empty brown square in Figure 7.

One of the most important trends is the higher deforestation rate measured in the Upper Niger basin (Kouroussa stream gauge) and the Konkouré basin (mostly in the basins of Pont de Linsan and Pont de la Route de Télimélé stations, secondarily Kaba and Nianso stations). These basins are the ones where:

- $\quad$ RC paradoxically decreases or remains low during the last period, which is characterized by rainfall recovery, possibly because natural reservoirs continue to be filled. Can this hypothesis however still be valid after nearly 25 years of rainfall recovery?

- DC increased strongly (downstream Konkouré basin), moderately (Kaba and Nianso stations), or inversely, and remained unchanged (Upper Niger at Kouroussa station).

- in Table 3, the basins where DC increased more than $20 \%$ are clearly not the ones where the deforestation rate was the highest (except the small Pt de Linsan-Upper Konkouré River basin).

\section{Analysis of LULCC}

\subsection{LULCC at the Regional Scale}

GFC2019 rasters reveal that the whole south area of the FD has a high value of vegetation cover; only the Upper Bafing basin is extensively deforested, corresponding to the most densely populated area: this is the extension of the 18th and 19th century Peul/Fulani confederation of small theocratic 
states which dominated West Africa. Deforestation in recent decades on the western side of the FD is not necessarily due to the extension of this high density of the upper plateaus area. It is more likely due to wood-charcoal extraction/forest exploitation. A very low number of blue pixels appear in Figures 7 and 8, reflecting the low vegetation gain detected by GFC2019, which is partly due to methodological reasons of vegetation density and vegetation height. The Bebele basin (Tene River at Bebele stream gauge station), which is presented in Figures 7 and 8, is not considered in this analysis, due to its very limited hydrological data set.

The northern areas on Figure 7 correspond to the driest Sudanian zone, covered with bushes, savannah, and low forest cover. Forest vegetation density falls below $15 \%$ here, and this limited vegetation is excluded by the vegetation cover threshold employed here.

\subsection{LULCC at the Upper Bafing Basin Scale}

Figure 9 is a map of the Mann-Kendall tau after applying, for each pixel, the $P$ value test at 0.001 and classifying in three categories: significant positive trend, stable or not significant trend, and significant negative trend.

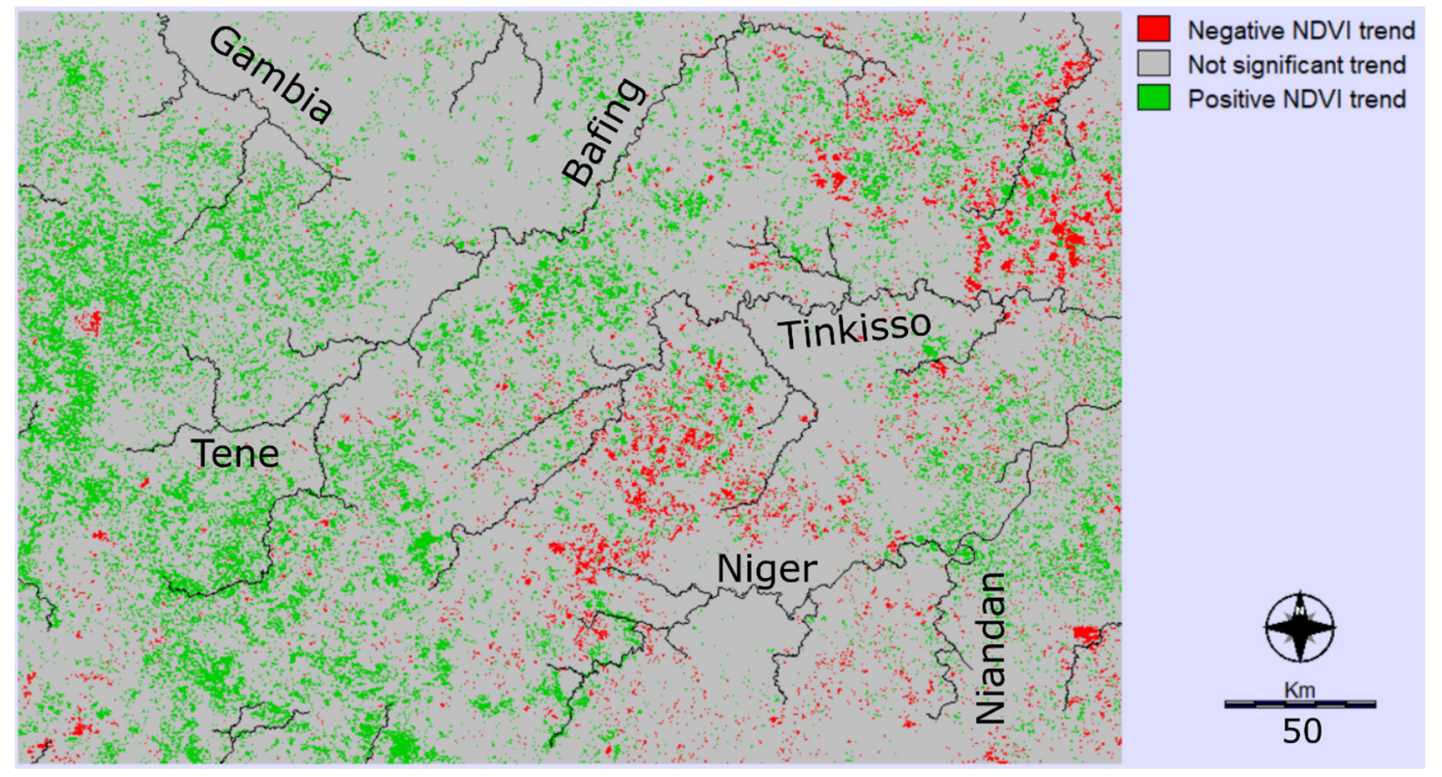

Figure 9. Evolution of vegetation cover (NDVI—normalized difference vegetation index) in the Upper Bafing Basin from February 2000 to February 2020. The area represented is the one of the empty blue rectangle in Figure 7.

Eighty-six percent of the zone covered by the map (Figure 9) has shown stable values of NDVI from 2000 to 2020 or non-significant trends according to the P value test at 0.001 , and 11\% of the zone has shown a significant positive trend (greening; biomass increase) for the same period. Only $3 \%$ has shown a significant negative trend (browning; biomass decrease).

Unlike the whole Fouta Djalon region, the Upper Bafing area is not concerned by important changes in its vegetation over the last 20 years, and the main change is a positive one for vegetation cover, even if it is hard to say without field validation if it corresponds to higher vegetation cover, higher biomass (either for spontaneous vegetation or for crops), or simple betterment of vegetative activities (i.e., phenology with longer green season).

The basins are not very different regarding this analysis. Stability ranges from $84.1 \%$ in the Bafing basin to $90.5 \%$ in the Niger basin (Figure 10). Negative trends range from $0.4 \%$ in the Gambia basin to $4.4 \%$ in the Tinkisso basin. Positive trends range from $6.3 \%$ to $14.6 \%$ in the Niger and Bafing basins, respectively. 


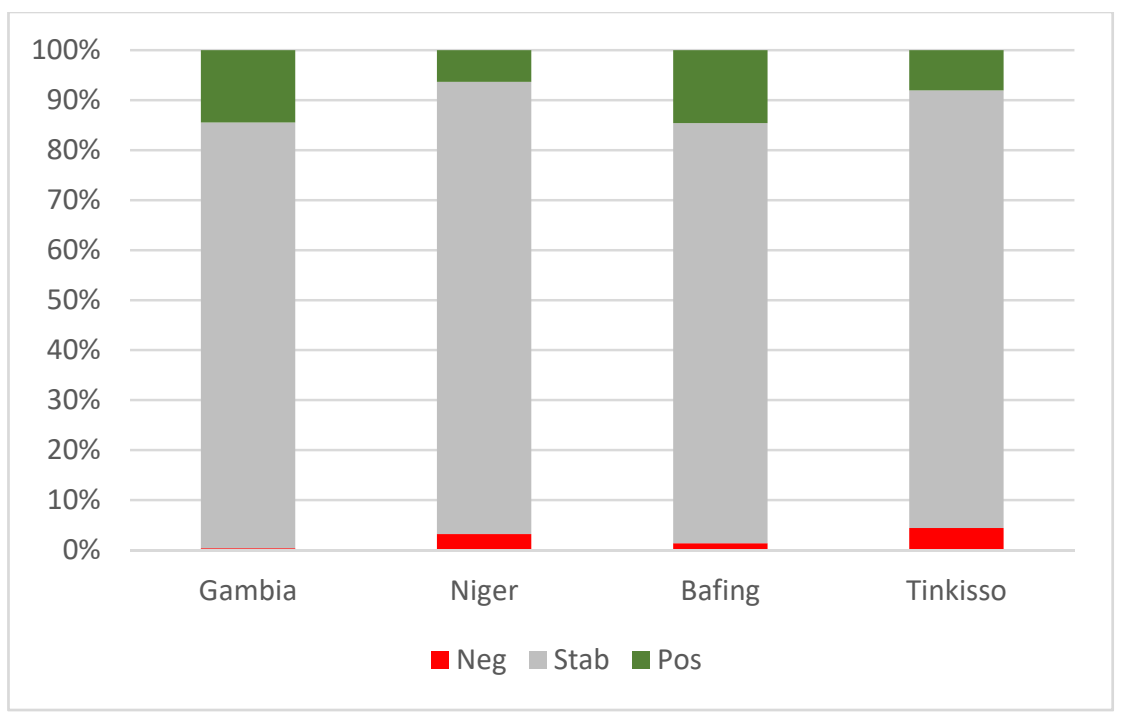

Figure 10. Part of the vegetation trends on the four main basins in the Bafing River basin.

\subsection{LULCC at the Sources Scale}

The comparison between the 1953 aerial picture (IGN—see Section 4.3 aerial mission in Guinea) and the Google Earth satellite scene (2019) does not demonstrate any apparent deforestations (Figure 11). The quality of both products being very different, it is difficult to do a classical numerical comparison, but the current situation (2019, on the right) seems a priori to be at least as forested as the one in 1953 (Figure 11). This area is named here the "three sources area": effectively, the two creeks (brooks) flowing through the north are the main sources of the Kouba (Koumba) River and the main upper reach of the Koliba River, which becomes the Rio Corubal in Guinea Bissau. The one flowing eastward is the Dima, the upper Gambia River. 'Ore Dima' means "the sources of the Dima River" in Pulaar language (Ore is the head). The other two rivers flowing southwards and the one flowing through the west are the main sources of the Kakrima River, the main tributary of the Konkouré River. This area is mostly composed by a doleritic bedrock.

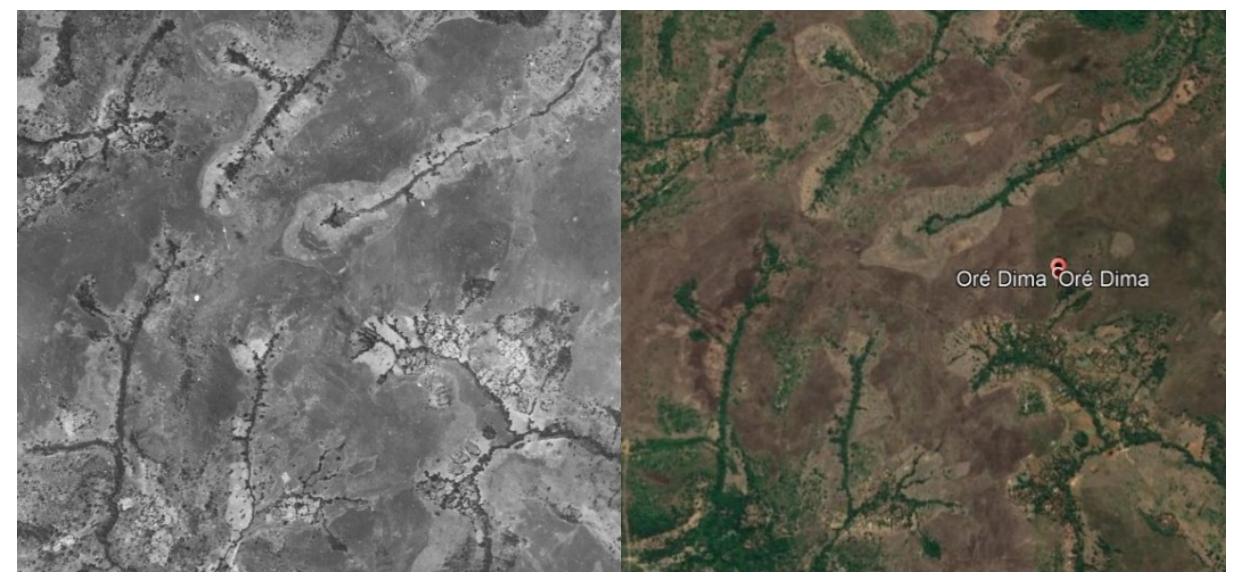

Figure 11. The so-called "three sources" area (15 km northward from Labé, the main city of the Fouta Djallon) in 1953 (IGN, left) and in 2019 (Google Earth@, right). No apparent deforestation. The extension of the picture is $5 \mathrm{~km}$ from the west to the east by $4.5 \mathrm{~km}$ from the north to the south. The area represented is the one of the red square in Figure 7.

Changes in vegetation cover evolution over time appear different at these three spatial scales but are difficult to compare considering the different analytical methodologies which are here applied 
across different areas, periods, and resolutions. However, clearly, some areas are being deforested, though results do not conclude that there is an overall deforestation, contrary to what is commonly described in the literature. Our three studies notably disagree in identifying negative trends in vegetation cover.

\subsection{Is There Any Synthesis Provided by Data Analysis?}

A PCA (Principal Component Analysis) is realized in order to provide clearer information about the variables and observations (basins) sampled in the FD. Table 4 details the variables considered in this analysis. The observations (sampling) are the 16 basins studied.

Table 4. List of the variables considered in the PCA analysis.

\begin{tabular}{cc}
\hline Q & Mean Yearly Discharge in $\mathrm{m}^{3} / \mathrm{s}$ \\
\hline QS & specific discharge $\left(1 \cdot \mathrm{s}^{-1} \cdot \mathrm{km}^{-2}\right)$ \\
QDX & maximum daily discharge \\
DC4 & depletion coef in 4 months \\
ED41 & DC4 evolution period 1 to per 2 \\
ED42 & DC4 evolution period 2 to per 3 \\
DC1 & depletion coef in 1 month \\
ED11 & DC1 evolution period 1 to per 2 \\
ED12 & DC1 evolution period 2 to per 3 \\
RAD & rainfall depth \\
RUD & runoff depth \\
RC & runoff coefficient \\
ER1 & RC evolution period 1 to per 2 \\
ER2 & RC evolution period 2 to per 3 \\
A & area \\
DEFO & \% deforestation 2000-2020 \\
\hline
\end{tabular}

No geological data are accounted for in this study, because it appears that there are no significant differences in the hydrological functioning of the different outcrops in the FD.

In both Figures 12 and 13:

- $\quad$ axis 1 (component 1 ) explains $46.4 \%$ of the total variance; it is mostly provided by QS, RAD, RUD, and RC (The definition of all abbreviations is given in Table 4).

- $\quad$ axis 2 (component 2 ) explains $23.8 \%$ of the variance, provided by Q, QDX, and A.

- $\quad$ axis 3 (component 3 ) explains 11.5\% of the variance, using DC4, ED41, ED11, and ER1.

- $\quad$ axis 4 (component 4 ) explains $7.6 \%$ of the variance, provided by ED42 and ED12.

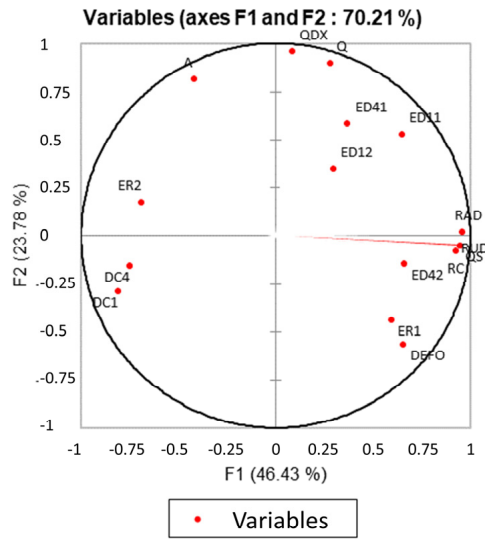

(a)

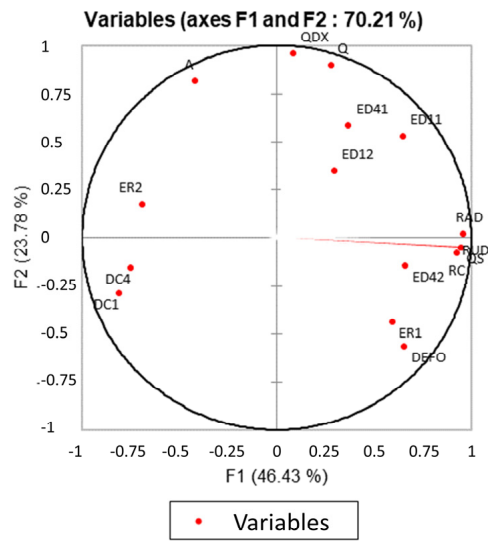

(b)

Figure 12. Variables spaces of the PCA (Principal Component Analysis) analysis; (a) components 1 and 2 ; (b) components 3 and 4. 
Observations (axes F1 and F2 : $70.21 \%$ )

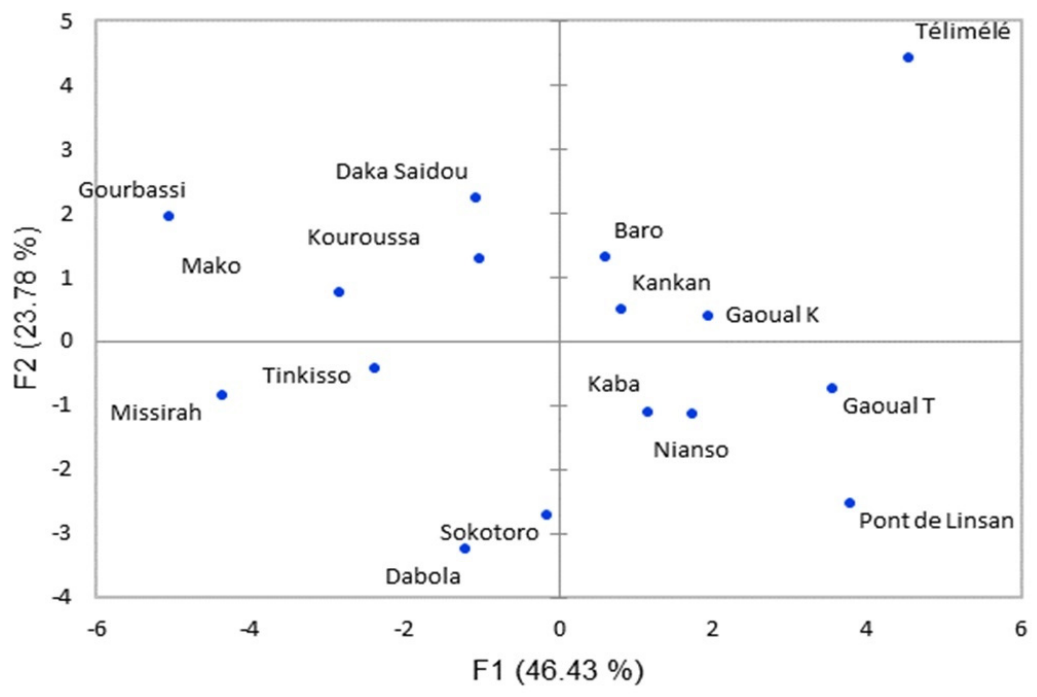

- Observations (basins)

(a)

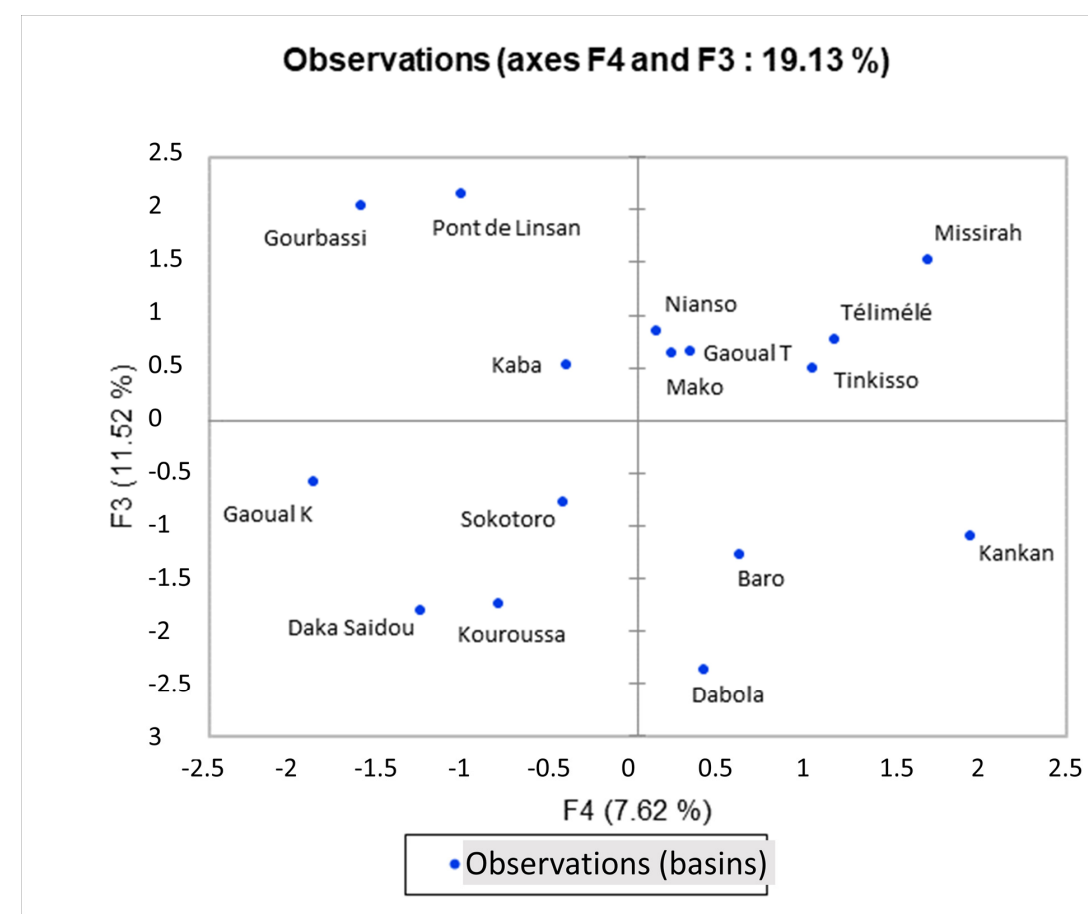

(b)

Figure 13. Observations spaces of the PCA analysis; (a): components 1 and 2; (b) components 3 and 4.

Figure 12a shows some redundancy of, on the one hand, hydrological variables (RAD, RUD, QS, $\mathrm{RC}$ ) and, on the other, the depletion coefficient, separated from their evolution in two different clusters. They are, by contrast, gathered according to axis 3 and axis 4 (Figure 12b). The LULCC is considered here through the regional mapping. Although its results are different (and locally contradictory) with the ones provided by the other LULCC analyses, we considered these to be suitable as relative values rather than as absolute values. The LULCC is also then determined with the same data and 
methods for the 16 basins. Deforestation as shown in Figure 7 is correlated with the increase in runoff between period 1 and 2, but negatively correlated with the increase in runoff between period 2 and 3 . Relative deforestation is clearly correlated with the increase in the DC (depletion coefficient) in four months during the second period, the one when rainfall recovery should have allowed a significant regreening. However, it is not so clearly correlated with the DC in one month (Figure 12a); yet following components 3 and 4 (Figure 12b), they seem more clearly correlated.

Figure 13 shows firstly a great dispersion of samples (basins) in all the statistical spaces, as evidence of their great geographical and hydrological diversity. Figure 13a seems logically dominated by runoff, and then, the basins of the western slope of the FDss and the ones coming off the Guinean Dorsale are clearly opposed to the ones of the northern part, where streamflow is weaker. No general trend appears in Figure 13b.

\section{Discussion}

The following points must be highlighted:

\subsection{The DC}

A strong interannual increase in the DC (see also [5,42]) is observed for the two main tributaries of the Upper Niger River from 1995. However, this is not observed in the Upper Niger (Kouroussa) nor in the Tinkisso River (Figure 6e). Otherwise, the DC, according to the three durations tested here, can be similar (e.g., in the Niandan River) or very different (e.g., in the Milo River)

A great deal was devoted to the DC during the 1990s and the 2000s by Mahé et al. [43,44] (1997 and 2001) and Olivry [18,19,21] (1987, 1993, 2002), as well as Bricquet et al. [20] (1997), Bamba et al. [45] (1996), and Sangaré et al. [46] (Figure 14). The latter showed that the DC increased from the beginning of the 1970s in all the basins, even if more slowly for the Sankarani River (one of the other main tributaries of the Upper Niger River, not investigated here). The exception was then the Milo River, the one whose DC has further increased in recent years. The DC of the Milo River only started its increase at the beginning of the 1980s [39]. A possible role of the basins' water-holding capacity remains to be investigated because the geological context is probably more complex than the schematic regionalization in Figure 2. The Upper Niger River basin is mostly a granitic basement one, however, Brunet Moret et al. (1986) [47] showed that there are sometimes sandstone outcrops in the lower basins of the Milo River. This could have served as a better water reservoir than granite and thus reduced the impact of the first drought spell in the 1970s. Another explanation can be provided by the rainfall's variation coefficient, which is lower in the Upper Milo basin than in most places in West Africa, as was noticed by Mahé et al. [44], most probably due to the specific relief orientation in the area. The Upper Milo basin runs through elevated areas both in the South and in the East, which seem to play a role in the reduction of the interannual variability, as is also observed in Central Ghana [44]. As can be seen (Figure 14) the DC of the Sankarani river also showed a reduced variability compared to that of other Upper Niger River tributaries, during the Great Drought. In the Senegal River basin, Bodian et al. (2020) [48] observed that the runoff recovery after the Great Drought lasted for five or ten years and is more significant for yearly and maximum discharge and less for low waters, which remain very weak. The same authors concluded that the high value of the DC for the Faleme River at Gourbassi (0.62) at the beginning of the 1980s (Figure 6d) can be attributed to a quasi-total drying up of the streamflow. A similar observation can be made for the Milo River during the 2010s (Figure 6e), but the reason remains to be explained since neither rainfall evolution nor the LULCC are satisfactory explaining factors for this behavior. 


\section{Niger River basin, tributaries, 1950-1990}

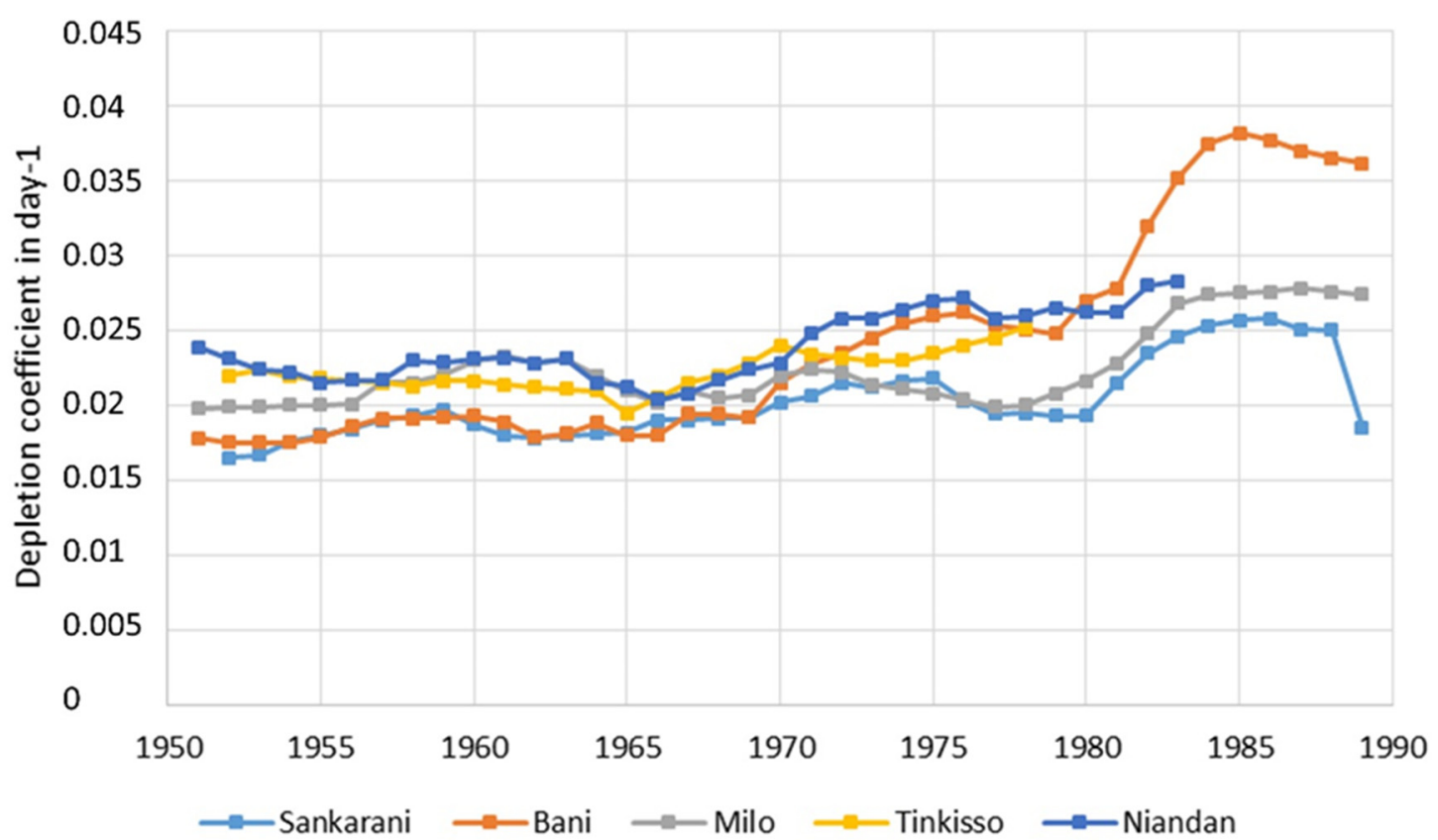

Figure 14. Evolution of DC in some Sudano-Guinean tributaries of the Niger River before and during the drought [41].

\subsection{LULCC (Land Use/Land Cover Change)}

As it has been shown above, vegetation cover in West Africa does not decline systematically though the population keeps on increasing at a rapid pace [5]. The Fouta Djallon is one of the best examples of this trend. A negative and Afro-pessimistic belief often links African deforestation with demographic growth. This stereotype anticipated catastrophic scenarios based on extensive peasant practices, which, against the background of strong demographic growth, should threaten the integrity of the Fouta Djallon ecosystems and therefore endanger the whole 'West African water tower'. In fact, local research has opened the debate on the reality and validity of such claims [49]. Brandt et al. (2017) [50] showed localized reductions in woodlands across West Africa but that farmland in Sahelian areas also promotes woody cover, contradicting simplistic ideas of a high negative correlation between population density and woody cover.

This strengthens the Boserupian point of view [51] (Boserup, 1965), increasingly accepted in the African scientific literature, as in Kenya [52], Niger [53], Northern Côte d'Ivoire [54], Northeastern Nigeria [55] or the whole Sudano-Sahelian strip [5,42]. This perspective is opposed to the catastrophist, Neo-Malthusian, and Afro-pessimistic general consensus of the second half of the 20th century.

Finally, it is worth noting that the 'tapades' traditional intensive gardening and tree cropping practices of the Fouta Djallon, which have played the role of man-made sponges though they have mostly been managed by women, are largely being abandoned. These practices should be rehabilitated in order to promote a sustainable agricultural intensification as the most useful way to infiltrate and store water in a catchment [5].

\subsection{Some Hydrological Consequences}

Except during the drought, the increase in the DC has only been observed in a few basins in recent years (the Konkouré and southern tributaries of the Upper Niger). The partial recovery in the RC (runoff coefficient), as well as the observed increase-at the regional scale-of the occurrence of extreme rainfall events $[36,42,56,57]$, has consequences for flooding frequency and intensity. 
This increases streamflow irregularities, accentuating low waters as well as floods. This could have impacts on hydraulic and civil engineering equipment and infrastructures. As illustrated in Figures 15 and 16, the bridges are threatened by some of these extreme flooding events.

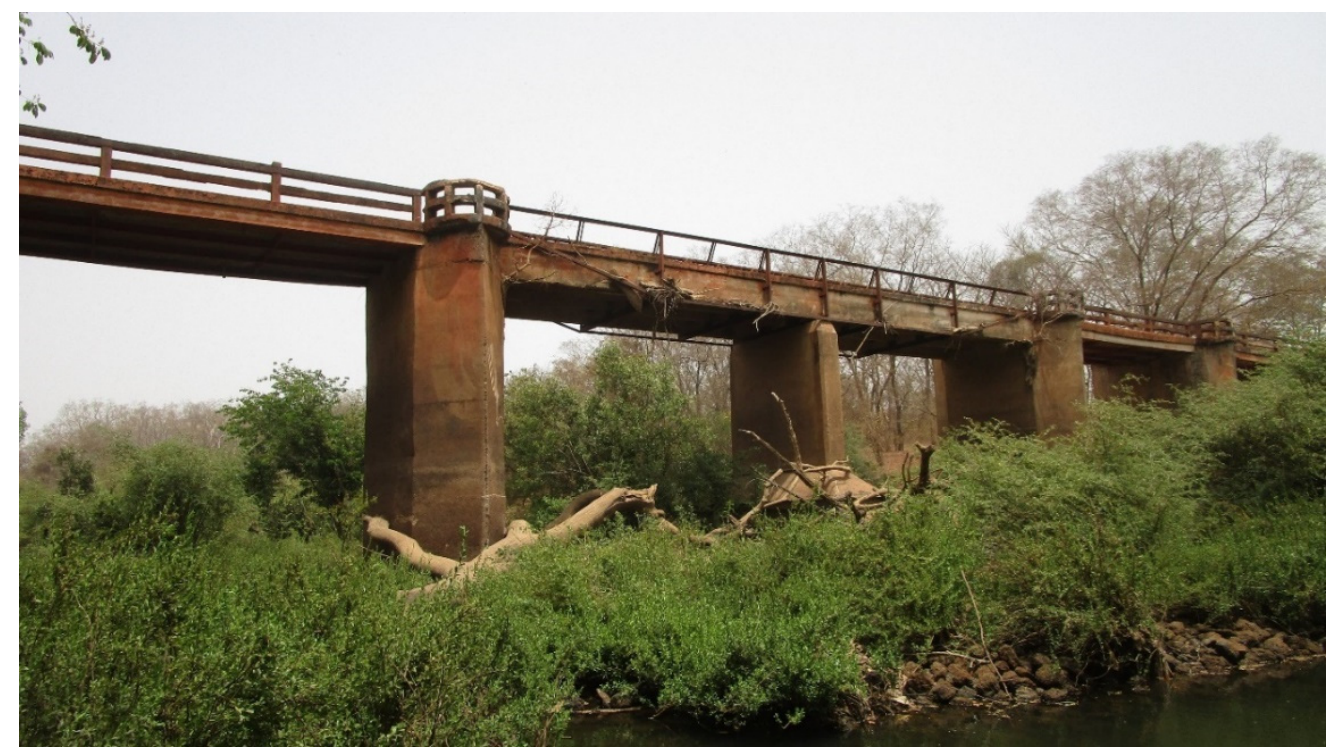

Figure 15. Bridge of the Koundara-Youkounkoun road, northern Guinea, on the Koulountou River. Built in the 1950s, it was flooded by the streamflow in August 2018, depositing whole trees (bottom) and wood debris (on the bridge deck).

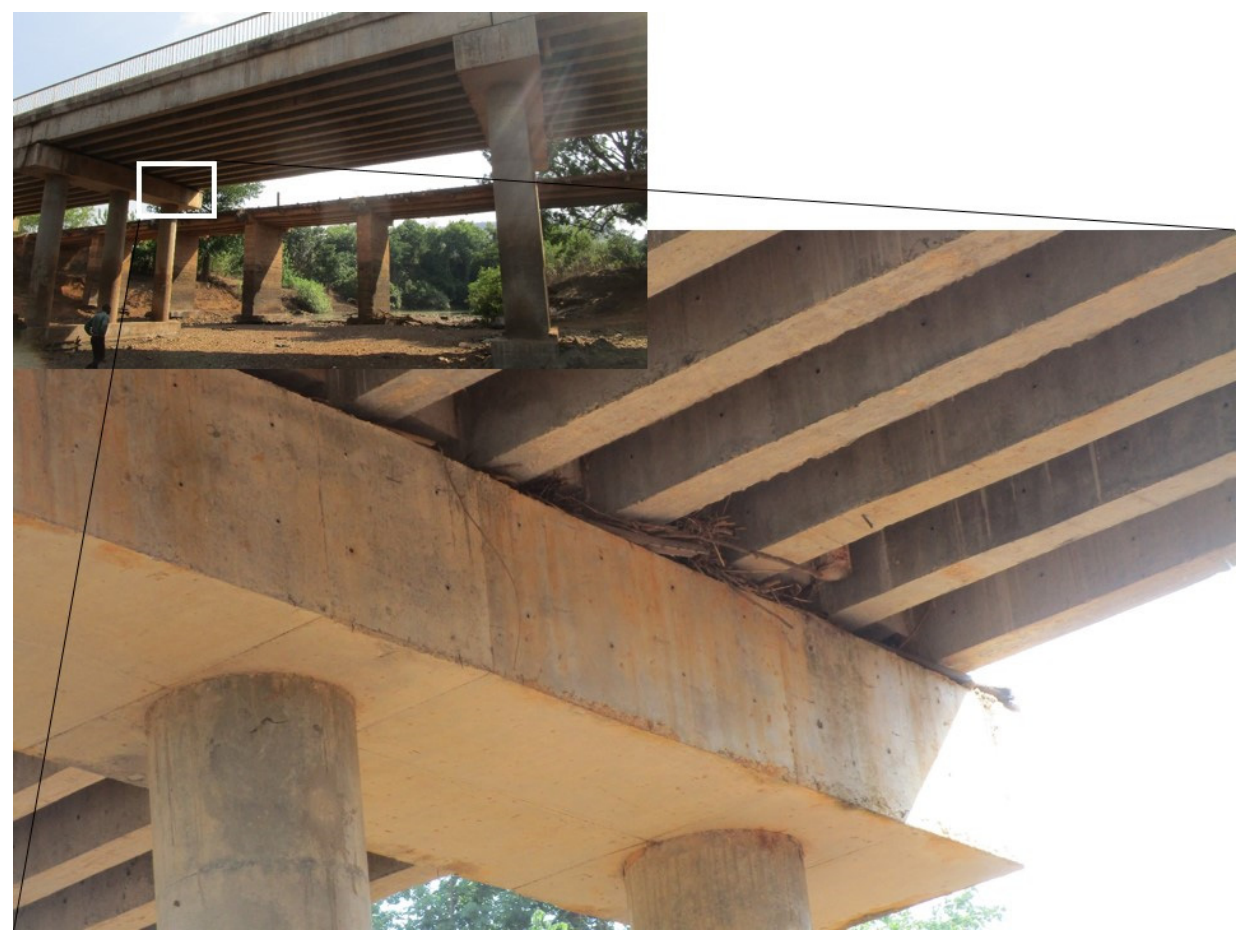

Figure 16. Pieces of branches blocked under the bridge deck of the new bridge of Komba on the Komba River (Upper Koliba/Corubal basin) after the flood of 2018. On the small picture: the new (2012) and, in the back, the ancient bridge (1950s). 
However, as this paper attempted to demonstrate, it is not necessarily the sign of a decrease in soil water-holding capacity attributable to LULCC. Depletion coefficients of the main rivers providing freshwater resources to the Sahel are decreasing due to the rainfall recovery. West African agro-ecosystems seem to be developing resilience, which could invert the observed trend and constitute rural resiliency models and sustainable development practices.

\section{Conclusions}

The Fouta Djallon seems to have suffered from a reduction in water-holding capacity during the drought (1970s and 1980s). However, after this dry period, in some basins and mostly in those flowing towards Sahelian areas, the expected decrease in the DC due to rainfall recovery is observed (the Niger at Kouroussa, the Falémé at Gourbassi, probably the Gambia and Corubal basin rivers). The Bafing at Daka Saidou did not show any increases in DC during the drought.

In the Upper Niger basin (the Milo and Niandan rivers), the Konkouré, and partially the Koliba/Tominé basins, a significant increase in the DC was noticed during the end of the recent 1994-2019 period. However, in the Upper Niger basin, the DC increased more in the basins where relative deforestation was lower (Milo and Niandan) and decreased slightly in the basin where relative deforestation was stronger (Upper Niger at Kouroussa). Following the PCA analysis, only the increase in the DC in four months between period 2 and period 3 is clearly correlated with relative deforestation. Besides the well-known and well-studied increase in rainfall intensity (increase in extreme events occurrence and increase in rainfall hourly mean intensity), the LULCC could be a discriminant factor of any increase in runoff and depletion coefficients, particularly in the Konkouré basin where deforestation remains an important dynamic. The PCA analysis only discriminates the southwestern basins (the Konkouré and Koliba/Tominé basins).

Contrary to popular belief, there is evidence of successful rural intensification practices in West Africa, which are generally characterized by an increasing vegetation cover and, locally, increasing tree cover. This kind of landscape should logically improve the soil and basins' water-holding capacity and eventually lead to a reduction in the DC (depletion coefficient). In the core of the FD (i.e., the FDss), the 'tapades' intensive system is disappearing, yet no deforestation is observed due to several combined patterns.

Since the sole increase in extreme rainfall events is unlikely to be responsible for the increase in the DC, LULCC seems to be a factor in the reduction in the basin water-holding capacity. However, it is statistically apparent only in the Konkouré and in the Koliba/Tominé basins, where annual rainfall is higher and where the runoff coefficients are significantly higher than in all the other basins, making their susceptibility to changes in runoff conditions more influential than in other basins.

The Fouta Djallon, as the West African water tower, does not appear as threatened. However, there is a stark difference between, on the one hand, the southwestern basins (the Konkoure and Upper Corubal), where LULCC seems to impact the basin water-holding capacity, and, on the other hand, basins such as the Gambia, Senegal, and Niger basins, which have been impacted more by the Great Drought but which are at least partially recovering their natural water storage capacity. This is an optimistic observation for the future of the West African Sahel, whose basins depend the most on the Fouta Djallon for its supply of fresh water resources.

Supplementary Materials: The following are available online at http://www.mdpi.com/2073-4441/12/11/2968/s1. Excel 1: 16 considered basins and the availability of their hydrological data. Figure S1a: Evolution of depletion coefficient, Konkouré River basin. Figure S1b: Evolution of rainfall and runoff coefficient, Konkouré River basin. Figure S2a: Evolution of depletion coefficient, Upper Konkouré River basin. Figure S2b: Evolution of rainfall and runoff coefficient, Konkouré River basin. Figure S3a: Evolution of depletion coefficient, Kokoulo River basin. Figure S3b: Evolution of rainfall and runoff coefficient, Kokoulo River basin. Figure S4a: Evolution of depletion coefficient, Kakrima River basin. Figure S4b: Evolution of rainfall and runoff coefficient, Kakrima River basin. Figure S5a: Evolution of depletion coefficient, Tominé River basin. Figure S5b: Evolution of rainfall and runoff coefficient, Tominé River basin. Figure S6a: Evolution of depletion coefficient, Koliba/Koumba River basin. Figure S6b: Evolution of rainfall and runoff coefficient, Koliba/KoumbaRiver basin. Figure S7a: Evolution of depletion coefficient, Koulountou River basin. Figure S7b: Evolution of rainfall and runoff coefficient, Koulountou 
River basin. Figure S8a: Evolution of depletion coefficient, Gambia River basin. Figure S8b: Evolution of rainfall and runoff coefficient, Gambia River basin. Figure S9a: Evolution of depletion coefficient, Faleme River basin. Figure S9b: Evolution of rainfall and runoff coefficient, Faleme River basin. Figure S10a: Evolution of depletion coefficient, Upper Bafing River basin. Figure S10b: Evolution of rainfall and runoff coefficient, Upper Bafing River basin. Figure S11a: Evolution of depletion coefficient, Bafing River basin Figure S11b: Evolution of rainfall and runoff coefficient, Bafing River basin. Figure S12a: Evolution of depletion coefficient, Upper Tinkisso River basin. Figure S12b: Evolution of rainfall and runoff coefficient, Upper Tinkisso River basin. Figure S13a: Evolution of depletion coefficient, Tinkisso River basin. Figure S13b: Evolution of rainfall and runoff coefficient, Tinkisso River basin. Figure S14a: Evolution of depletion coefficient, Upper Niger River basin. Figure S14b: Evolution of rainfall and runoff coefficient, Upper Niger River basin. Figure S15a: Evolution of depletion coefficient, Niandan River basin. Figure S15b: Evolution of rainfall and runoff coefficient, Niandan River basin. Figure S16a: Evolution of depletion coefficient, Milo River basin. Figure S16b: Evolution of rainfall and runoff coefficient, Milo River basin.

Author Contributions: Conceptualization, L.D., B.F., S.P.M. and A.B.D.; data curation, B.F., S.P.M., A.B.D., S.S. (Safietou Soumaré), F.B.S.D., A.D., K.D. (Kadiatou Diallo), J.A. (Julien Andrieu), I.A., J.-C.B., A.B. (Aliou Barry), A.B. (Ansoumana Bodian), Y.B., N.B., J.-L.C., H.D., G.D., M.D., K.D. (Kourahoye Diallo), A.F., E.G., L.F., L.K., B.N.N., Y.S., S.S. (Saly Sambou) and B.A.T.; formal analysis, B.F., S.P.M., A.B.D., J.A. (Julien Andrieu), A.O., J.A. (Jean Albergel), and J.-C.B.; funding acquisition, J.A. (Julien Andrieu), I.A., J.A. (Jean Albergel), J.-C.B., A.B. (Aliou Barry), A.B. (Ansoumana Bodian), and Y.B.; investigation, S.P.M., A.B.D., S.S. (Safietou Soumaré), B.F., F.B.S.D., A.D., K.D. (Kadiatou Diallo), and J.-P.V.; methodology, A.B.D., S.S. (Safietou Soumaré), J.A., G.M., A.O., D.O., and B.F.; project administration, L.D., J.A. (Julien Andrieu), G.M., J.A. (Jean Albergel), A.O., and D.O.; resources, F.B.S.D., A.D., and K.D. (Kadiatou Diallo); software, B.F., F.B.S.D., and K.D. (Kourahoye Diallo); supervision, J.-P.V., L.A.L., J.-C.O. and L.D.; validation, G.M., J.A. (Julien Andrieu), A.O., D.O., L.A.L., and J.-P.V.; visualization, F.B.S.D., A.D., and K.D. (Kadiatou Diallo); writing—original draft, L.D., B.F., S.P.M., and A.B.D.; writing一review and editing, L.D., B.F., S.P.M., and A.B.D.; G.M., J.A. (Julien Andrieu), A.O., J.-C.B., D.O., L.A.L., and J.-P.V. All authors have read and agreed to the published version of the manuscript.

Funding: This research was funded by the European Union, via AICS (Agenzia Italiana de Cooperazione per il Sviluppo, grant number ENV/2017/383-744/AP n) 01/2019/WEFE SENEGAL for the OMVS, Senegal River Basin Agency.

Acknowledgments: The authors warmly acknowledge the Rivers Basins Agency (NBA, OMVS and OMVG) as well as the Direction of Hydraulics of Guinea for providing the daily discharge data, and the SIEREM and AMMA Catch databases as well as the ANACIM (Senegalese Met Office) for the daily rainfall data. We kindly acknowledge the reviewers who allowed us to propose a deeply improved version of the manuscript.

Conflicts of Interest: The authors declare no conflict of interest.

\section{References}

1. L'Hôte, J.-P.; Mahé, G. Afrique Centrale et de l'Ouest: Précipitations Moyennes Annuelles (Période 1951-1989); IRD (Orstom): Bondy, France, 1996; 1 map.

2. Aurouet, A.; Ferry, L.; Cougny, G.; ECOWAS. Atlas de l'eau du Massif du Fouta Djalon-Le Château d'eau de l'Afrique de l'Ouest/Fouta Djallon Highland-Water Atlas; CEDEAO (ECOWAS), IWA, Anteagroup, The World Bank: Washington, DC, USA, 2017; p. 114. Available online: http://documents.banquemondiale.org/curated/ fr/844511520436091243/pdf/123986-WP-P150210-FRENCH-PUBLIC.pdf (accessed on 11 April 2020).

3. Gebrehiwot, S.G.; Gardenas, A.I.; Bewket, W.; Seibert, J.; Ilstedt, U.; Bishop, K. The long-term hydrology of East Africa's water tower: Statistical change detection in the watersheds of the Abbay Basin. Reg. Environ. Chang. 2013. [CrossRef]

4. Blanc, P. De l’Egypte à l'Ethiopie, quand la puissance se déplace en Afrique Nilotique. In Confluences Méditerranée; L’Harmattan: Paris, France, 2014; ISSN 1148-2664; ISBN 9782343045627. Available online: https://www.cairn.info/revue-confluences-mediterranee-2014-3-page-123.htm (accessed on 21 June 2020).

5. Descroix, L. Processus et Enjeux d'eau en Afrique de l'Ouest Sahélo-Soudanienne; Editions Des Archives Contemporaines: Paris, France, 2018; 320p, ISBN 9782813003140. [CrossRef]

6. Boulvert, Y. Approche Synthétique des Aplanissements Cuirassés de Centrafrique et de Guinée (Conakry). 2005. Available online: http://horizon.documentation.ird.fr/exl-doc/pleins_textes/divers19-10/010038259.pdf (accessed on 18 April 2020).

7. Mamedov, V.I.; Boufeev, Y.V.; Nikitine, Y.A. Geology of the Republic of Guinea; Geoprospects and State University Lomonossov of Moscow: Moscow, Russia, 2010; 326p. 
8. Boulvert, Y. Repères Historiques sur la Caractérisation du Cuirassement et de la Géomorphologie Guinéenne. Conférence à l'Université de Conakry, Conakry (GIN), 1998/04. Available online: https://numerisud.ird.fr/documents-et-films/publications/Reperes-historiques-sur-la-caracterisation-ducuirassement-et-de-la-geomorphologie-guineenne (accessed on 18 April 2020).

9. Orange, D. Hydroclimatologie du Fouta Djallon et Dynamique Actuelle d'un Vieux Paysage Latéritique. Ph.D. Thesis, Université Louis Pasteur de Strasbourg, Strasbourg, France, 1990; 232p. Available online: https://www.persee.fr/doc/sgeol_0302-2684_1992_mon_93_(accessed on 30 October 2018).

10. Orange, D.; Gac, J.-Y. Reconnaissance géochimique des eaux du Fouta Djalon (Guinée), flux de matières dissoutes et en suspension en Haute-Gambie. Géodynamique 1990, 5, 35-49.

11. Michel, P. Les Bassins des Fleuves Sénégal et Gambie, Etude Géomorphologique; ORSTOM: Bondy, France, 1973; 810p.

12. D'Aubreville, A. Erosion et "bovalisation" en Afrique noire française. L'Agron. Trop. 1947, 2, 339-357.

13. Maignien, R. Compte-rendu de recherches sur les latérites. In Colloquium on Laterites, Madagascar 1964; Reports on Natural Ressources, $n^{\circ} 4$; UNESCO: Paris, France, 1966; 155p.

14. Richard-Molard, J. Les traits d'ensemble du Fouta-Djalon. Rev. Géograph. Alp. 1943, XXXI, 199-213. [CrossRef]

15. Pouquet, J. Le plateau de Labé (Guinée française, A.O.F). Remarques sur le caractère dramatique des phénomènes d'érosion des sols et sur les remèdes proposés. Bull. l'IFAN (Inst. Fr. d'Afr. Noire) 1956, 18, 1-16.

16. Pouquet, J. Quelques types d'évolution du relief en Guinée française: Processus hydrographiques et phénomènes de cuirassement sur les hautes surfaces du Fouta-Dialon (AO.F.). In Proceedings of the Eighteenth Internacional Congress of Geography, Rio de Janeiro, Brazil, 9-18 August 1956; pp. 350-361.

17. Sudres, A. La dégradation des sols au Foutah Djalon. L'Agron. Trop. 1947, I, 227-246.

18. Olivry, J.-C. Synthèse des Connaissances Hydrologiques et Potentiel en Ressources en Eau du Fleuve Niger; Provisional Report; World Bank, Niger Basin Authority: Niamey, Niger, 2002; 160p.

19. Olivry, J.-C. Les conséquences durables de la sécheresse actuelle sur l'écoulement du fleuve Sénégal et l'hypersalinisation de la Basse-Casamance. In The Influence of Climate Change and Climatic Variability on the Hydrologic Regime and Water Resources; Proceedings of the Vancouver Symposium; IAHS Publ. No. 168: Wallingford, UK, 1987; 12p.

20. Bricquet, J.-P.; Bamba, F.; Mahé, G.; Touré, M.; Olivry, J.-C. Evolution récente des ressources en eau de l'Afrique atlantique. Rev. Sci. l'Eau 1997, 3, 321-337. [CrossRef]

21. Olivry, J.-C.; Bricquet, J.-P.; Mahé, G. Vers un appauvrissement durable des ressources en eau de l'Afrique humide? In Hydrology of Warm Humid Regions. Proceedings of the 4th Assembly IAHS, Yokohama, Japan, 13-15 July 1993; Gladwell, J.S., Ed.; Publication IAHS 216: Wallingford, UK, 1993; pp. 67-78.

22. Gomis, D.E.R. Synthèse Hydrologique Du Fleuve GAMBIE en Amont de Gouloumbou; Master Memory; UCAD: Dakar, Senegal, 2000; 166p.

23. Bodian, A.; Dacosta, H.; Dezetter, A. Analyse des débits de crues et d'étiages dans le bassin versant du fleuve sénégal en amont du barrage de Manantali. Clim. Dev. 2013, 15, 46-56.

24. Samoura, K. Contributions Méthodologiques à L'évaluation Environnementale Stratégique De L'exploitation du Potentiel Hydroélectrique des Bassins Côtiers en Milieu Tropical: Cas du Konkouré, en Guinée. Ph.D. Thesis, UQAM, Montreal, QC, Canada, 2011; 304p.

25. Tallaksen, L.M. A review of baseflow recession analysis. J. Hydrol. 1995, 165, 349-370. [CrossRef]

26. Boyer, J.F.; Dieulin, C.; Rouché, N.; Crès, A.; Servat, E.; Paturel, J.E.; Mahé, G. SIEREM: An environmental information system for water resources. In Water Resource Variability: Hydrological Impacts. Proceedings of the 5th FRIEND World Conference, Havana, Cuba, November 2016; IAHS Publ.: La Havana, Cuba, 2006; Volume 308, pp. 19-25.

27. Dieulin, C.; Mahé, G.; Paturel, J.-E.; Ejjiyar, S.; Tramblay, Y.; Rouché, N.; El Mansouri, B. A new 60-year 1940-1999 monthly gridded rainfall data set for Africa. Water 2019, 11, 387. [CrossRef]

28. Funk, C.; Peterson, P.; Landsfeld, M.; Pedreros, D.; Verdin, J.; Shukla, S.; Husak, G.; Rowland, J.; Harrison, L.; Hoell, A.; et al. The climate hazards infrared precipitation with stations-A new environmental record for monitoring extremes. Sci. Data 2015, 2, 150066. [CrossRef] [PubMed]

29. Hansen, M.C.; Potapov, P.V.; Moore, R.; Hancher, M.; Turubanova, S.A.; Tyukavina, A.; Thau, D.; Stehman, S.V.; Goetz, S.J.; Loveland, T.R.; et al. High-Resolution Global Maps of 21st-Century Forest Cover Change. Science 2013, 342, 850-853. [CrossRef] [PubMed] 
30. Gorelick, N.; Hancher, M.; Dixon, M.; Ilyushchenko, S.; Thau, D.; Moore, R. Google Earth Engine: Planetary-scale geospatial analysis for everyone. Remote Sens. Environ. 2017, 202, 18-27. [CrossRef]

31. Gilbert, R.O. Statistical Methods for Environmental Pollution Monitoring; Van Nostrand Reinhold: New York, NY, USA, 1987; ISBN 0-442-23050-8.

32. San Emeterio, J.-L.; Alexandre, F.; Andrieu, J.; Génin, A.; Mering, C. Changements socio-environnementaux et dynamiques des paysages ruraux le long du gradient bioclimatique nord-sud dans le sud-ouest du Niger (régions de Tillabery et de Dosso. VertigO Rev. Electron. Sci. L'Environ. 2013, 13. Available online: http://journals.openedition.org/vertigo/14456 (accessed on 12 October 2015). [CrossRef]

33. Andrieu, J. Phenological analysis of the savanna-forest transition from 1981 to 2006 form Côte d'Ivoire to Benin with NDVI NOAA time series. Eur. J. Remote Sens. 2017. [CrossRef]

34. Andrieu, J. Vegetation change analysis in Côte d'Ivoire during conflicts using a phenological metric and Kendall correlation of two NDVI time series (Text in French). Tropicultura 2018, 36, 258-270. Available online: http://www.tropicultura.org/text/v36n2/258.pdf (accessed on 9 November 2019).

35. Nicholson, S.E. On the question of the "recovery" of the rains in the West African Sahel. J. Arid Environ. 2005, 63, 615-641. [CrossRef]

36. Ali, A.; Lebel, T. The Sahelian standardized rainfall index revisited. Int. J. Climatol. 2009, 29, $1705-1714$. [CrossRef]

37. Nicholson, S.E. The West African Sahel: A review of recent studies on the rainfall regime and its interannual variability. Int. Sch. Res. Not. 2013, 2013, 453251. [CrossRef]

38. Descroix, L.; Diongue Niang, A.; Panthou, G.; Bodian, A.; Sané, T.; Dacosta, H.; Malam Abdou, M.; Vandervaere, J.-P.; Quantin, G. Evolution Récente de la Mousson en Afrique de l'Ouest à Travers Deux Fenêtres (Sénégambie et Bassin du Niger Moyen). Climatologie 2015, 12, 25-43.

39. Ardoin-Bardin, S.; Dezetter, A.; Servat, E.; Paturel, J.-E.; Mahé, G.; Niel, H.; Dieulin, C. Using general circulation model outputs to assess impacts of climate change on runoff for large hydrological catchments in West Africa. Hydrol. Sci. J. 2009, 54, 77-89. [CrossRef]

40. Biasutti, M. Forced Sahel rainfall trends in the CMIP5 archive. J. Geophys. Res. Atmos. 2013, 118, 1613-1623. [CrossRef]

41. IPCC. Climate Change Synthesis Report; IPCC, WMO: Geneva, Switzerland, 2014; 167p.

42. Descroix, L.; Guichard, F.; Grippa, M.; Lambert, L.A.; Panthou, G.; Gal, L.; Dardel, C.; Quantin, G.; Kergoat, L.; Bouaïta, Y.; et al. Evolution of surface hydrology in the Sahelo-Sudanian stripe: An updated synthesis. Water 2018, 10, 748. [CrossRef]

43. Mahé, G.; Bamba, F.; Diabaté, M.; Diarra, A.; Diarra, M. The reduction of the water resources on upper basins of the Niger river: Hydrological balances and analysis of the depletion curves (1951-1989). Poster proceedings, Sustainability of water ressources under increasing uncertainty. In Proceedings of the 5th IAHS Assembly, Rabat, Maroc, 23 April-3 May 1997; pp. 9-12.

44. Mahé, G.; L'Hôte, Y.; Olivry, J.C.; Wotling, G. Trends and discontinuities in regional rainfall of west and central Africa-1951-1989. Hydrol. Sci. J. 2001, 46, 211-226. [CrossRef]

45. Bamba, F.; Mahé, G.; Bricquet, J.P.; Olivry, J.C. Changements climatiques et variabilité des ressources en eau des bassins du Haut Niger et de la Cuvette Lacustre. In Réseaux Hydrométriques, Réseaux Télématiques, Réseaux Scientifiques: Nouveaux Visages de l'Hydrologie Régionale en Afrique; Fritsch, J.M., Paturel, J.E., Servat, E., Eds.; XIIèmes Journées Hydrologiques de l'ORSTOM: Montpellier, France, 1996; 26p.

46. Sangaré, S.; Mahé, G.; Paturel, J.-E.; Bangoura, Y. Bilan hydrologique du fleuve Niger en Guinée de 1950 à 2000. Sud Sciences et Technologies 2002, 9, 21-33. Available online: https://horizon.documentation.ird.fr/exldoc/pleins_textes/divers16-04/010034319.pdf (accessed on 18 June 2017).

47. Brunet Moret, Y.; Chaperon, P.; Lamagat, J.-P.; Molinier, M. Monographie Hydrologique du Fleuve Niger; Orstom: Paris, France, 1986; 800p.

48. Bodian, A.; Diop, L.; Panthou, G.; Dacosta, H.; Deme, A.; Dezetter, A.; Ndiaye, P.M.; Diouf, I.; Vischel, T. Recent Trend in Hydroclimatic Conditions in the Senegal River Basin. Water 2020, 12, 436. [CrossRef]

49. André, V.; Pestaña, G. Les visages du Fouta-Djalon. Les Cah. d'Outre-Mer 2002, 217. Available online: http://com.revues.org/index1038.html (accessed on 11 September 2014). [CrossRef]

50. Brandt, M.; Rasmussen, K.; Peñuelas, J.; Tian, F.; Schurgers, G.; Verger, A.; Mertz, O.; Palmer, J.R.B.; Fensholt, R. Human population growth offsets climate-driven increase in woody vegetation in sub-Saharan Africa. Nat. Ecol. Evol. 2017, 1, 0081. [CrossRef] 
51. Boserup, E. The Conditions of Agricultural Growth: The Economics of Agrarian Change under Population Pressure; (Republished 1993: Earthscan Publications: London, UK); Allen and Unwin: London, UK, 1965.

52. Tiffen, M.; Mortimore, M.; Gichuki, F. More People, Less Erosion: Environmental Recovery in Kenya; John Wiley \& Sons: London, UK, 1994; 311p.

53. Luxereau, A.; Roussel, B. Changements Ecologiques et Sociaux au Niger; Etudes Africaines; L'Harmattan Ed: Paris, France, 1997; 239p.

54. Demont, M.; Jouve, P. Evolution d'Agro-Systèmes Villageois Dans la Region de Korhogo (ord Côte d'Ivoire): Boserup vs. Malthus, Opposition ou Complémentarité? Dynamiques Agraires et Construction Sociale Du Territoire; Séminaire CNEARC-UTM: Montpellier, France, 2000; pp. 93-108.

55. Mortimore, M.J.; Adams, W.M. Farmer adaptation, change and \&crisis' in the Sahel. Glob. Environ. Chang. 2001, 11, 49-57.

56. Panthou, G.; Vischel, T.; Lebel, T. Recent trends in the regime of extreme rainfall in the Central Sahel. Int. J. Climatol. 2014, 34, 3998-4006. [CrossRef]

57. Panthou, G.; Lebel, T.; Vischel, T.; Quantin, G.; Sané, Y.; Ba, A.; Ndiaye, O.; Diongue-Niang, A.; Diop Kane, M. Rainfall intensification in tropical semi-arid regions: The Sahelian case. Environ. Res. Lett. 2018, 13, 064013. [CrossRef]

(C) 2020 by the authors. Licensee MDPI, Basel, Switzerland. This article is an open access article distributed under the terms and conditions of the Creative Commons Attribution (CC BY) license (http://creativecommons.org/licenses/by/4.0/). 